Puede citar este artículo como:

López Rodríguez, Carlos. «Vidas enfrentadas: Pere Maça de Liçana y Eximèn Pérez de Corella. Enemistad personal, rivalidad señorial y conflictos políticos en el reino de Valencia (14201450)». Anales de la Universidad de Alicante. Historia Medieval, N. 19 (2015-2016): 343-379, DOI:10.14198/medieval.2015-2016.19.12

\title{
VIDAS ENFRENTADAS: PERE MAÇA DE LIÇANA Y EXIMĖN PÉREZ DE CORELLA. ENEMISTAD PERSONAL, RIVALIDAD SEÑORIAL Y CONFLICTOS POLÍTICOS EN EL REINO DE VALENCIA (1420-1450) ${ }^{1}$
}

\author{
Carlos López Rodríguez \\ Archivo de la Corona de Aragón
}

\section{RESUMEN}

Entre 1420 y 1450, los nobles valencianos Eximèn Pérez de Corella y Pero (o Pere) Maça de Liçana mantuvieron duros enfrentamientos, algunos armados, entre ellos y a través de sus vasallos, fundamentalmente en las comarcas del sur del reino de Valencia, pero con ramificaciones que se extendieron a las instituciones de la Corona. Estos conflictos surgían de la rivalidad entre una familia de barones de rancia estirpe en declive (los Maça de Liçana) y otra de caballeros recientemente ennoblecidos (los Corella) que con sus servicios a la nueva dinastía Trastamara crecían en fortuna y poder. En estos enfrentamientos convergían rivalidades jurisdiccionales y por el dominio territorial, enemistades personales y envidias sociales, que acabaron tomando un cariz político y que son reflejo de la cultura y acción política de la nobleza valenciana en la primera mitad del siglo XV. Sus actitudes se definían por su

\footnotetext{
1 Abreviaturas utilizadas: ACA: Archivo de la Corona de Aragón; AMV: Archivo Municipal de Valencia; ARV: Archivo del Reino de Valencia; cap.: capítulo; cit.: citado; doc.: documento; f.: folio; ff.: folios; fl.: florines; lib.: libro; m.: mano; MR: Maestre Racional; núm.: número; p.: página; r: recto; RC: Real Cancillería; reg.: registro; s.: sueldos; s. b.. sueldos barceloneses; s.r.: sueldos de reales de Valencia; v: vuelto; vol.: volumen; ZURITA: ZURITA, Jerónimo, Anales de la Corona de Aragón, ed. A. Canellas López, Zaragoza. Agradezco al Sr. Vicent Baydal su amable invitación a participar en este número.
} 
posicionamiento ante el servicio al soberano y el favor del rey. Respondían, pues, a dos pautas de comportamiento muy características de la nobleza del siglo XV en los estadios inmediatamente anteriores a la consolidación de una monarquía absoluta.

Palabras clave: Eximèn Pérez de Corella; Pero Maça de Liçana; Corona de Aragón; Reino de Valencia; Conflictos nobiliarios.

\section{SUMMARY}

Between 1420 and 1450 the Valencian noblemen Eximèn Pérez de Corella and Pero (or Pere) Maça de Liçana maintained heavy disputes, sometimes armed, between them and through their vassals, mainly in the regions of the South of the Kingdom of Valencia, but with ramifications that extended to the institutions of the Crown. These conflicts arose from the rivalry between a family of barons of noble but declining lineage (the Maça de Liçana) and a recently ennobled family (the Corella) who grew in fortune and power thanks to their services to the new dynasty of the Trastamaras. In these confrontations, jurisdictional rivalries for territorial domain, personal feuds and social envy converged, and these ended up taking political overtones and rivalries which reflected the culture and political action of the Valencian nobility in the first half of the fifteenth century. Their attitudes were defined by their positioning to the service to the sovereign and the favor of the King. Thus they responded to two patterns of behavior that are very characteristic of the nobility in the fifteenth century in the stages prior to the consolidation of an absolute monarchy.

Keywords: Eximèn Pérez de Corella; Pero Maça de Liçana; Crown of Aragon; Kingdom of Valencia; Nobility confrontations.

En febrero de 1449, el noble Luis Cornell presentó ante el lugarteniente general del reino de Valencia, don Juan de Navarra, una súplica contra Joan Roís de Corella. Como don Juan no pudo entender en ella por falta de tiempo, encargó el conocimiento de la causa al Consejo Real de Valencia, «maiorment attesa la condició de les persones e quant comprenen les cases de aquelles en aqueix Regne », encareciendo su resolución por vía de justicia, «car molt més valgué per aquesta via lo fet haia desexida que si.s havian a pendre per ells altres camins desviats per deffalliment de justícia». ${ }^{2}$

¿Quiénes eran tan poderosos personajes, capaces de arruinar el orden público del reino? Luis Cornell era hijo de Pero Maça de Liçana, y Joan Roís

2 ARV, Real, reg. 237, f. $12 \mathrm{v}$. 
de Corella lo era de Eximèn Pérez de Corella. Unos y otros pertenecían al reducido grupo de barones, el estrato superior de la nobleza, compuesto por algo más de veinte linajes. El enfrentamiento entre los hijos era un episodio más en una larga historia de conflictos entre los padres, en la que durante treinta años se mezclaron rivalidades jurisdiccionales, enemistades personales y envidias sociales, que son reflejo de la cultura y acción política de la nobleza valenciana en la primera mitad del siglo XV. Para entender su fuerte oposición, hay que conocer los orígenes de ambas familias.

\section{LOS MAÇA DE LIÇANA}

Los Maça de Liçana remontaban su ascendencia a la alta aristocracia aragonesa de la más rancia estirpe. El linaje había nacido de la fusión de dos familias de ricoshombres aragoneses, los Maça y los Liçana (Maza y Lizana en su forma aragonesa) hacia 1352 o poco antes. ${ }^{3} \mathrm{El}$ solar de los Lizana estaba en el castillo del mismo nombre, hoy despoblado, ubicado en el término de Barbuñales, cerca de Barbastro. Su posición es muy alta desde tiempos remotos. Rodrigo Lizana fue uno de los nobles que combatieron con el rey Pedro el Católico en la batalla de las Navas de Tolosa en 1212. Desde entonces, tenemos bien documentada su actividad: abandona a su señor en Muret, ${ }^{4}$ participa en los bandos y parcialidades que se sucedieron en la minoría y primera juventud de Jaime I, y ya en 1218 es uno de los grandes hombres que se sienta en el consejo del rey. Desempeñó un papel destacado en la conquista de Valencia, por lo que fue recompensado con los lugares de Montroi, Bunyol y Macastre, ${ }^{5}$ además de otras casas en la capital, incluido un horno, ${ }^{6}$ y con el nombramiento como primer procurador del reino. ${ }^{7}$ También el linaje aragonés de los Maça era muy antiguo. Pedro (I) Maza, señor de Sangarrén, acompañó a Pedro el Católico en la batalla de las Navas. Desde 1229, figura con frecuencia junto a Jaime I. Intervino en la fase final de la conquista de Valencia, especialmente en los sitios de Xàtiva y Biar. ${ }^{8}$ Fue recompensado

3 ESQUERDO, O., Nobiliario valenciano, [Valencia, 1963], p. 148.

4 ZURITA, II, 61, p. 334; y II, 63, p. 348; y Les quetre grans cróniques. Crònica o Llibre dels feits, ed. de Ferran SOLDEVILA, Barcelona, 1971, cap. 9, p. 6.

5 Llibre del Repartiment de Valencia, edición dirigida por Antoni Ferrando, Valencia, 1978, asientos núms. 214 y 2.216; y CABEZUELO PLIEGO, J.V., Poder público y administración territorial en el reino de Valencia, 1239-1348. El oficio de la procuración, Valencia, 1998, pp. 39-40.

$6 \quad$ Llibre del Repartiment cit., asientos núms 261, 1.149, 1.540, 1.796, 2.291, 3.546 y 3.855 .

7 MATEU IBARS, J., Los virreyes de Valencia. Fuentes para su estudio, Valencia, 1963, pp. 51-52; ZURITA, III, 37, p. 539.

8 ZURITA, passim. 
con casas en la ciudad ${ }^{9}$ y la alquería de la Llosa de Godella (con hornos pero sin molinos). ${ }^{10}$ Hijo suyo fue Blasco (I) Maza, a quien vemos al costado de Rodrigo de Lizana en muchos de los acontecimientos de la minoría de Jaime I. Desde 1231, es uno de los grandes consejeros del soberano, al cual ayuda en la conquista del reino de Valencia. En recompensa, le correspondió la alquería de Alèdua, junto a Torralba, y unas casas en la capital, que fueron consideradas muy buenas. ${ }^{11}$

Sus descendientes participaron activamente en la vida política de la época. Los Maça se asentaron en Moixent, que se convirtió en su feudo principal. ${ }^{12}$ Pedro (III) Maza de Lizana (el primero del apellido compuesto, según parece) prestó valiosos servicios al Ceremonioso. Permaneció al lado del rey en las guerras de la Unión, lo que le valió librarse de represalias durante las campañas de Lope de Luna en $1348 .{ }^{13}$ Fue uno de los once individuos no titulados o de sangre real que integraban el grupo de los nobles (opuesto al de los simples caballeros) del brazo militar durante las Cortes valencianas de 1358, compuesto entonces por 65 individuos. ${ }^{14}$ Durante más de cuarenta años fue señor de Jumilla, hasta que le fue ocupada esta villa, lo que provocó la chispa que encendió la guerra con Castilla. ${ }^{15}$ Durante este conflicto, demostró gran valor en numerosos episodios. ${ }^{16}$ Fue apresado y llevado al reino enemigo, donde murió antes del 20 de junio de 1364. ${ }^{17}$

Había casado con Isabel Cornell, hija de Luis Cornell, señor de Alfajarín, nieto a su vez de Beatriu d'Aragó, hija natural de Pedro el Grande. Del matrimonio nació, hacia 1362, Pero (IV) Maça de Liçana, señor de Moixent, cuya

$9 \quad$ Llibre del Repartiment cit., asientos núms. 3.369 y 3.774.

$10 \quad$ Llibre del Repartiment cit., asientos núms. 358 y 2.228.

$11 \quad$ Llibre del Repartiment cit., asientos núms. 902, 2.208, 2.248, 3.639 y 3.869.

12 Según ZURITA, VIII, 24, p. 115, un Pedro Maza fue hijo de Gonzalo García, y tenía indiviso con Pedro Fernández de Híjar el dominio de los lugares de Belchite y La Puebla de Albortón. En 1301, Gonzalo García compró este feudo a la hija de la princesa Láscara, infanta de Grecia, a quien pertenecía al menos desde 1288 (ACA, RC, reg. 78, f. 46v; y reg. 198, ff. 307v-308). En 1330, Alfonso IV concedió el mero imperio sobre Moixent a Gonzalo García, lo que fue confirmado por Pedro IV en 1336 (ACA, RC, reg. 482, ff. 106-107 y reg. 862, ff. 93v-95; y también en ARV, Real, reg. 495, ff. 156v-157v).

13 ZURITA, VIII, 24, p. 115.

14 MUÑOZ POMER, M. R., «La oferta de las Cortes de Valencia de 1358», Saitabi, XXXVI (1986), pp. 163-164; y RIUS SERRA, J., «Cortes de Valencia de 1358», Anuario de Historia del Derecho Español, XVII (1946), pp. 663-682.

15 ZURITA, IX, 16, pp. 351-352. Con más detalle, RIQUER, M. de, Vida i aventures del cavaller valencià don Pero Maça, Barcelona, 1984, pp. 17-20.

16 ZURITA, IX, 3, p. 301; 7, p. 314; 14, p. 344; 17, p. 357.

17 RIQUER, M. de, Vida cit., p. 18-20, según el documento conservado en ACA, RC, reg. 1.903, f. 236; ZURITA, IX, 45, p. 461; ACA, RC, reg. 1198, f. 234. 
infancia transcurrió bajo la tutoría de su madre, la custodia de sus parientes maternos y la protección del monarca, que no olvidó al deudo de su antiguo servidor. ${ }^{18}$ El 16 de septiembre de 1379, Pere (IV) Maça de Liçana obtuvo, por rescripto real, la mayoría de edad a los 17 años. ${ }^{19}$ A partir de entonces, y desde Moixent, cuyo castillo como el de Jumilla tiene en feudo por el rey, ${ }^{20}$ la actividad política del joven Maça es intensa. El 2 de septiembre de 1379, todavía menor de edad legal, ya figura entre los principales componentes de la facción de los Centelles, enfrentada a los Vilaragut en la ciudad de Valencia. ${ }^{21}$ Apenas un año más tarde, en el verano de 1380, fue nombrado por el reino de Valencia como una de las personas que habían de tratar la cuestión del Cisma. ${ }^{22}$ En todo momento cuenta con la benevolencia del monarca. ${ }^{23} \mathrm{La}$ reina Violante le vendió en 1392 la villa de Novelda, a la que sumó el castillo de La Mola, y un año más tarde, en mayo de 1393, estos lugares, por concesión de Juan I, mediante un documento expedido por Bernat Metge, le fueron concedidos en franco alodio, incluida la jurisdicción, ${ }^{24}$ ampliada a la criminal en otro privilegio expedido en agosto de ese año, entre otras concesiones. ${ }^{25}$ Estos privilegios venían motivados por la preparación de la campaña de Cerdeña, para combatir la nueva rebelión de la isla. El 14 de agosto de 1393 Pero Maça de Liçana fue nombrado capitán general de la armada. ${ }^{26}$ Poseía además los lugares de Alcàntera y Enguera, en Valencia, cuyo mero y mixto imperio vendió para preparar su expedición naval. ${ }^{27}$ En abril de 1394, pasó a

18 Isabel Cornell fue nombrada tutora de su hijo en 1367 (ACA, RC, reg. 914, f. 90v), sucediendo a Berenguer Mercader, albacea testamentario del padre (ACA, RC, reg. 1.617, f. $27 \mathrm{v}$ ). Son numerosas las muestras de atención al menor dadas por el monarca: en 1366, donándole cinco caballerías (RIQUER, M. de, Vida cit., pp. 29-30); en 1370, autorizando la venta del lugar de Mirla (ACA, RC, reg. 1.782, ff. 65v-66r); en 1372, poniéndolo expresamente bajo su protección (ACA, RC, reg. 922, ff. 88v-89r); en 1378, concediendo un subsidio para reparar los daños provocados por una inundación en la torre del castillo de Moixent (ACA, RC, reg. 1.262, f. 110r).

19 ACA, RC, reg. 934, f. 112r.

20 ACA, RC, reg. 2.009, f. 11.

21 CARRERES, S., Notes per a la història dels bandos de València, Valencia, 1930, pp. 41-42.

22 ZURITA, X, 28, p. 668.

23 En 1383, el rey le autorizó a recaudar sisas en Moixent y Font de la Figuera (ACA, RC, reg. 1.287 , f. $88 \mathrm{v})$.

24 ACA, RC, reg. 1.903, ff. 236-238; y también en ARV, Real, reg. 495, ff. 165v$169 \mathrm{v}$.

25 El peaje sobre Moixent y Font de la Figuera (ACA, RC, reg. 1.907, ff. 97-98); la jurisdicción a los crímenes de «plagi i collera» (ACA, RC, reg. 1.906, ff. 122v-123r); los bienes confiscados a cierto individuo judaizante huido a Berbería (ACA, RC, reg. 1.905$, f. $172 \mathrm{v})$.

26 RIQUER, M. de, Vida cit., p. 32.

27 ARV, Real, reg. 495, ff. 165v-169v. También en ACA, RC, reg. 1.934, ff. 131v-135r. 
Cerdeña aunque, sobre la marcha, la flota cambió su rumbo para dirigirse en socorro de Martín el Viejo y Martín el Joven, asediados en la ciudad siciliana de Catania. Allí murió de enfermedad en agosto de 1394. ${ }^{28}$

De su primer matrimonio con Isabel de Alagón había nacido en agosto de 1384 su hijo homónimo, Pero o Pere (V) Maça de Liçana, señor de Monòver, que es el que aquí nos interesa. Tuvo también a Blasco Maça de Liçana, que sirvió a Alfonso $\mathrm{V}$ en las guerras de Nápoles y fue dotado en aquel reino. En segundas nupcias, casó con Blanca de Centelles, y de este matrimonio nació Isabel Maça de Liçana, quien en 1422 tomó matrimonio con Eximèn Pérez d'Arenós. Se le conoce al menos un hijo natural, Francesc Maça de Liçana, legitimado por el rey Martín en $1403^{29}$ y muerto en 1468 , el cual en 1437 tomó matrimonio con una rica doncella de una familia de la caballería media, Beatriu Carbonell, de no tan alta condición como los enlaces que celebraron los hijos legítimos.

Parece que los asuntos de nuestro Pero (V) Maça de Liçana estuvieron a cargo de Bernat Metge, gran amigo de su padre. ${ }^{30}$ Contó también con la protección del monarca, que en noviembre de 1394 le concedió las cinco caballerías de las que ya disfrutaba su progenitor desde los tiempos del Ceremonioso. ${ }^{31}$ La sombra del rey (o de Bernat Metge) lo ampara en su infancia. El mismo mes de noviembre de 1394 se formalizó la venta que la reina Violante hizo de $2.000 \mathrm{~s}$. censales, por precio de 30.000 s., sobre las rentas de Cocentaina y su morería, a favor del pupilo Pere Maça de Liçana, hijo del difunto Pere Maça de Liçana, ${ }^{32}$ lo que tendrá su importancia en el futuro, como veremos. Muy joven, en septiembre de 1397, visita la corte pontificia de Aviñón, en el séquito de Ramon de Perellós, vizconde de Perellós y de Roda, a quien acompañó en su extraordinario viaje a Irlanda, donde sería armado caballero, y durante el cual pasó por las cortes de los reyes de Francia e Inglatera. ${ }^{33}$ Casó con Brianda Cornell, hija a su vez de su tío abuelo Luis Cornell y Brianda de Luna, hermana de María de Luna, esposa de Martín el Humano. Pero Maça de Liçana, pues, estaba emparentado con la Casa real, además de con las más nobles familias aragonesas y valencianas. ${ }^{34}$ Tan altas relaciones debieron forjar un carácter fuerte, por lo demás muy común en la

\footnotetext{
RIQUER, M. de, Vida cit., pp. 29-35; y ZURITA, X, 52, pp. 772-774.

RIQUER, M. de, Vida cit., p. 53; ACA, RC, reg. 2.198, f. 261.

RIQUER, M. de, Vida cit., pp. 34 y 39-40.

RIQUER, M. de, Vida cit., p. 39.

ACA, RC, reg. 1.937, ff. 121v-124.

RIQUER, M. de, Vida cit., pp. 39-46.

34 CERVERÓ, Ll. i BATLLORI, M., «El comte Dionís d`Hongria, senyor de Canals, al seguici de la reina Violante: la descendència de Dionís als regnes de València i d`Aragó», en X Cogreso de Historia de la Corona de Aragón, vol. Comunicaciones, 1 y 2, pp. 559577.
} 
nobleza de la época, agudizado en su caso por la impronta de las gestas de sus antecesores. Las fuentes lo muestran como un individuo de temperamento vivo e independiente, con cierta actitud levantisca hacia Martín I. ${ }^{35}$ En 1403 , el rey le ordenó prestar fidelidad y homenaje por el castillo de Moixent. ${ }^{36}$ Como su padre, cuyos pasos parece seguir, en 1404 milita en la facción de los Centelles contra los Vilaragut, en Valencia. ${ }^{37}$ Las treguas impuestas por el rey en estas parcialidades y la orden de salir de la ciudad parecen inducirle a la rebeldía: el incumplimiento de este mandato le lleva a ser condenado por los tribunales reales a una multa de $10.000 \mathrm{fl.} .^{38}$ En realidad, lo que le acarreó esta multa fue la confiscación de sus tierras en nombre del rey, hecho que a su vez provocó ciertas disensiones entre Martín I y su esposa (pariente lejana suya), movida a clemencia por el recuerdo de los servicios prestados por el padre de Pero Maça. ${ }^{39}$ Acaso estos tropiezos le llevaron a emprender en 1405 un viaje a Sicilia -del cual no hay noticia cierta- con compañías de ballesteros al servicio del rey Martín. ${ }^{40}$

Estas aventuras juveniles debieron alimentar la soberbia de Pero Maça de Liçana, que debía ser proverbial: en 1407, el rey le dirigió una carta para que diera de sus bienes los alimentos necesarios a Isabel Cornell, su abuela ya sexagenaria por entonces.$^{41}$ Este carácter orgulloso y temperamental le acompañó toda su vida y está en la raíz de algunos de sus comportamientos políticos. Su mismo aspecto físico debía ser imponente: según Onofre Esquerdo, fue apodado «el Barbudo». ${ }^{42}$ Habiendo afrontado graves penas como cabecilla del bando de los Centelles en los principios de su vida pública, ya en 1408 y 1409, acompañado de su hermano borde Francesc, cruzó cartas de batalla con Guillem Ramon Centelles, por lo que se adscribió al bando de los Vilaragut. Nuevamente hubo altercados, detenciones domiciliarias y expulsiones. ${ }^{43}$ Entre 1407 y 1410 otra vez entabló bandos con los Centelles, rivales a su vez de los Vilaragut, por el dominio de Xàtiva. ${ }^{44}$ Pero durante el Interregno volvió a su antigua militancia con los Centelles, con quienes firmó treguas hasta la designación del rey sucesor. ${ }^{45}$ Asistió al llamado Parlament de

35 RIQUER, M. de, Vida cit., pp. 49-52.

36 ACA, RC, reg. 2.316, ff. 69v-70r.

37 RIQUER, M. de, Vida cit., pp. 49-50.

38 ACA, RC, reg. 2.277 , f. $26 \mathrm{v}-27 \mathrm{v}$.

39 RIQUER, M. de, Vida cit., pp. 49-52.

40 RIQUER, M. de, Vida cit., p. 52.

${ }^{41}$ ACA, RC, Cartas reales, Martín I, núm. 1.080.

42 ESQUERDO, O., Nobiliario valenciano cit., p. 152.

43 RIQUER, M. de, Vida cit., pp. 52-54.

44 CARRERES, S., Notes cit., p. 135; DIAGO, F., Apuntamientos, [Valencia, 1936-42], vol. I, pp. 89 y ss.

45 RIQUER, M. de, Vida cit., pp. 57. 
fora, que reunió a los partidarios de Fernando de Antequera. ${ }^{46}$ Como podía esperarse de él, realizó algunos hechos de armas notables por el valor que demostraban, pero con pocos resultados prácticos. El 30 de diciembre de 1411 llegó a ejecutar la hazaña de escalar la villa de Elche, lo que obligó a sus enemigos a movilizar mil hombres de a caballo y diez mil de a pie. ${ }^{47}$ Son golpes de mano que, a juzgar por los testimonios que tenemos, recuerdan más al bandolero que al militar: el 27 de mayo de 1412 mató al lugarteniente de justicia de Valencia en el patio del convento de los franciscanos de esa ciudad. ${ }^{48}$ Declarado Fernando de Antequera como rey de Aragón, en septiembre de 1412 Pero Maça, junto con otros caballeros del bando de los Vilaragut, al cual había regresado de nuevo, firmó la paz con los Centelles, sancionada por el monarca un mes más tarde..$^{49}$

Con la paz, cambiaron las preocupaciones de nuestro caballero, que se dedicó a cuidar de su patrimonio. Según el genealogista Esquerdo, en 1412 vendió la baronía y lugares de Lizana, en Aragón, para pagar las deudas contraídas por su familia a causa de las guerras de Sicilia. De ser cierto, este dato es interesante para comprender su reticencia a las campañas italianas del Magnánimo, años más tarde. No contento con la ampliación de dominios conseguida por su padre, siempre mostró una gran ambición de poder. De sus aspiraciones podemos hacernos una idea a través de los enlaces familiares que planeó para sus hijos y descendientes. Sabemos que Pero Maça de Liçana «el barbudo»-que testó en 1448- casó en primeras nupcias con Brianda Cornell (nieta de Lope de Luna, conde de Luna, y sobrina de la reina María de Luna). ${ }^{50}$ De este matrimonio nacieron tres hijos. El primogénito fue otro Pero Maça de Liçana, que cambió su nombre por el de Luis Cornell por disposiciones testamentarias, tomando así las armas y apellido de aquella gran familia. ${ }^{51}$ Como vimos, el último Luis Cornell fue hermano de Isabel Cornell, tío del almirante Pero Maça y tío-abuelo, por tanto, de Pere Maça «el barbudo». En 1436, Luis Cornell Maça de Liçana era señor de la baronía Alfajarín, en Aragón, y como tal acudió a las Cortes de Alcañiz de ese año. ${ }^{52}$ Éste con-

46 ZURITA, XI, 21, pp. 68-69; MARTÍNEZ ALOY, J., La Diputación de la Generalidad del reino de Valencia, Valencia, 1930, p. 184. Los asistentes al Parlament de fora, según el proceso de Cortes, en AMV, yy, 4.

ZURITA, XI, 61, pp. 184-185. RIQUER, M. de, Vida cit., p. 56, sitúa esta hazaña en Alzira.

48 Cfr. RIQUER, M. de, Vida cit., p. 57.

49 ACA, RC, reg. 2.361, ff. 51r-52r; reg. 2.397, ff. 35v-36v; reg. 2.399, ff. 2v-4r y ss.; y RIQUER, M. de, Vida cit., p. 58.

50 RIQUER, M. de, Vida cit., pp. 54-56.

51 CERVERÓ, Ll. i BATLLORI, M., «El comte Dionís d'Hongria» cit., p. 570.

52 ZURITA, XIV, cap. 35. 
trajo a su vez tres matrimonios: con Constanza Ávalos (hija del condestable de Castilla), en 1425, a cuya boda Zurita dedica alguna atención, por el gran estado de los contrayentes; ${ }^{53}$ con Aldonza de Castro y con Beatriu de Próxita. A pesar de los tres enlaces, murió en 1463 sin sucesión. Dejó como heredero universal a su sobrino, Pere Maça. El segundo hijo de Pero Maça y Brianda Cornell fue Martí Maça de Liçana, que casó con Rafaela de Rocafull, otra gran familia noble valenciana, de quien nacieron otro Pero Maça y otro Luis Cornell. La tercera hija de Pero Maça y Brianda Cornell, Blanca, tomó matrimonio con el caballero catalán Huc de Mur, del cual nacieron Brianda (casada en 1465 con Nicolau Carròs d'Arborea, virrey de Cerdeña) e Isabel (casada en 1471 con Pedro de Urrea). Zurita menciona otra hija de Pero Maza y Brianda Cornell llamada Brianda Maza, que casó con Juan de Luna, señor de Illueca, muerto en $1438 .^{54}$ El segundo matrimonio de Pero Maça de Liçana «el barbudo» fue con Leonor Boïl, del cual nacieron al menos dos hijos muertos sin sucesión. ${ }^{55}$

\section{LOS CORELLA}

Los orígenes de los Corella eran más modestos, aunque también antiguos. Procedían de la localidad de este nombre en Navarra, de donde salieron los hermanos Sancho y Pedro Rodrigo de Corella para servir a Jaime I en la conquista de Valencia. ${ }^{56}$ Por esta razón a este último, que continúa la línea principal de la familia, el Conquistador lo dotó en 1238 con cuatro jobadas en la alquería de Mililla y varias casas en la ciudad. ${ }^{57}$ En 1271, el rey le dió la torre y alquerías de Olocaiba y Petrer, ${ }^{58}$ además de tierras en Albaida y otros lugares. Le empeñó también los castillos de Alcalà de Gallinera con sus

53 ZURITA, XIII, cap. 40.

54 ZURITA, XIV, cap. 51, p. 184.

55 ESQUERDO, O., Nobiliario valenciano cit., pp. 137-139.

56 Y allí se establecieron: en 1258 el rey consignó a Sancho de Corella los derechos sobre Dénia y el castillo de Segarra (ACA, RC, reg. 10, ff. 64v-65r). Diez años más tarde, el rey le encomendó el castillo del Buey Negro, con dieciocho hombres para que lo guardasen (ibídem, reg. 17, f. 92v; y reg. 35, f. 61r). Rindió cuentas por este castillo en 1270 (ibídem, reg. 35, f. 2r). Un año más tarde, se le concedieron 1.000 s. anuales para prestar servicio al rey según costumbre de Aragón (ibídem, reg. 35, f. 63v). Al menos desde marzo de ese año, era baile de Gandia y, más tarde, de Beniopa (ibídem, reg. 37, ff. 14r, 49r y 63r). Ya en 1272 el monarca le confirmó sus propiedades y heredades en Gandia y Ondara (ibídem, reg. 37, f. 52r). En 1277, el rey Pedro le concedió el castillo de Ademús (ibídem, reg. 40, f. 31v).

57 Llibre del Repartiment cit., asientos núms. 108, 659, 3.327 y 3.761.

58 ACA, RC, reg. 21, f. 7r. 
derechos. ${ }^{59}$ Pedro el Grande mandó darle posesión de Olocaiba en $1278 .{ }^{60}$ A un hijo de este Pedro Roís de Corella, también llamado Pedro y muerto hacia $1329,{ }^{61}$ le concedió Jaime II, el 10 de noviembre de 1303, 1.000 s. b. por haber tomado recientemente la caballería de manos del mismo rey. ${ }^{62}$ En enero de 1314, el monarca le otorgó 2.000 s. r. sobre los ingresos de la Bailía General de Valencia (aunque según una nota de la Cancillería el rey revocó esta concesión en 1318). ${ }^{63}$ Por los servicios prestados por Rodrigo (Roís) de Corella y por sus antecesores, en 1314 Jaime II le concedió diez jobadas de tierra en el marjal de Bairén. ${ }^{64}$ Casó con Beatriu Castellà y de Llançol y de este matrimonio nació Antoni Roís de Corella, también servidor de Jaime II y padre de Pere Roís de Corella, que desempeñó cargos como jurado y justicia criminal de Valencia entre 1344 y 1349. Este Pere Roís de Corella fue cabecilla de la Unión, y por ello el rey Pedro le confiscó sus bienes en 1349. ${ }^{65}$ También se confiscaron a Joan Roís de Corella, su hermano acaso, como líder de la Unión. ${ }^{66}$ Fue este uno de los cuatro caballeros unionistas ejecutados en 1348 , con una muerte denigrante. ${ }^{67}$

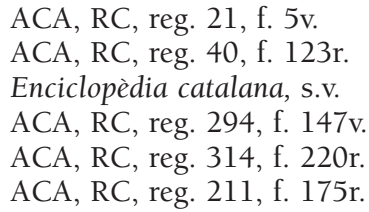

ACA, RC, reg. 21, f. 5v.

ACA, RC, reg. 40 , f. 123 r.

Enciclopèdia catalana, s.v.

ACA, RC, reg. 294, f. 147v.

ACA, RC, reg. 314 , f. 220 r.

ACA, RC, reg. 211, f. 175r.

5 A Pere Roís de Corella, consejero municipal en 1347 y justicia criminal de la ciudad de Valencia en 1348, le imputaron los jueces reales ser «gran cap de la Unió» (Diplomatari de la Unió del Regne de València, ed. a cura de Mateu Rodrigo Lizondo, Valencia, 2013, docs. 51, 73, 141, 153, 159 y 163). Era señor de la alquería de Mililla, próxima a la ciudad de Valencia, y de otras dos alquerías en término de Dénia, Gata y Neclas, además de una casa ubicada en la parroquia de Sant Andreu de la ciudad de Valencia, y de 500 s. censales sobre el lugar de Otavell. Todas estas propiedades, así como cualquier otro bien inmueble o mueble fueron adjudicadas por el rey a Berenguer d'Abellà (ACA, RC, reg. 888, f. 198r-v). La relación de sus bienes y rentas según la encuesta incoada contra él por la justicia real en 1348, en Diplomatari cit., doc. 153, p. 290.

Diplomatari cit., docs. 26, 130, 151, 153, 163, 165. Según los jueces reales, sus bienes consistían en «lo loch de Almussafes; ítem lo castel de Locayba, lo loch de Pedrager e altres alqueries en terme de Dénia, e açò solia valer .X. millia solidos de renda -açò és en terme de l'infant en Pere. Ítem ha un bon alberch en València, franch e quiti» (Diplomatari cit., doc. 153, p. 292). Esta casa, sita en la parroquia de Sant Andeu en Valencia, fue adjudicada a la escribanía real, para que allí se guardaran las bulas, sellos y registros (ACA, RC, reg. 888, f. 191r-v). Almussafes, que había comprado a Ramon de Escorna, fue donado a Garcia de Lloris (ACA, RC, reg. 887, f. 129r; y reg. 1.315, f. 180r-v). Olocaiba y Petrer, con las alquerías de Rafal, Montroy, Canyelles, Binicau y Aguilar, con las cuales había dotado a sus antecesores el Conquistador, fueron vendidas a Mateu Mercer (ACA, RC, reg. 992, f. 75r-78r). Estas expropiaciones tuvieron que ser enmendadas por el monarca, a instancias de Francesca de Corella, hija y heredera de Joan Roís de Corella (ACA, RC, reg. 1.313, f. 36r-v; ACA, RC, reg. 992, ff. 140v-145v). ZURITA, Anales, VIII, 33, p. 168. La sentencia en Diplomatari cit., doc. 165. 
De Pere Roís de Corella fue hijo otro Pere Roís de Corella, señor de Canet y casado con una hija de Ramon de Sentllir, llamada Alamanda. Otro hijo fue Joan Roís de Corella, jurado de Valencia en 1382 y 1400, que casó con Isabel Eiximenis Llançol, heredera de su anterior marido, Roger de Sentllir. ${ }^{68}$ De ese matrimonio nacería Eximèn Pérez de Corella, primer conde de Cocentaina, nuestro protagonista. Este Joan Roís de Corella, doncel y señor de Pardines, pudo recuperar el antiguo estatus perdido por su familia tras los acontecimientos de la Unión ya que, con el tiempo, los Corella habían regresado al servicio del soberano. ${ }^{69}$ Según los cronistas, en 1390, Juan I, con motivo de entrar en batalla contra los franceses invasores del Rosellón y en consideración a los servicios prestados y a la antigüedad de su linaje, dio el grado de nobleza a varios caballeros, entre ellos los Corella. ${ }^{70}$ Pero la documentación de que disponemos retrasa esta fecha a 1407, cuando Martín I promovió a Joan Roís de Corella a la nobleza. ${ }^{71}$

Eximèn Pérez de Corella nació hacia $1400 .{ }^{72}$ Por razones testamentarias adoptó ocasionalmente el nombre de Ramon de Sentllir. Casó con Beatriu Llançol, hija de otra familia de la caballería. Pero ya sus descendientes toman mujeres entre los linajes baronales: su hijo Joan casó con Francesca de Moncada, y su hijo Héctor con Constança de Vilanova, hija de Antoni de Vilanova; el hijo de ambos, Francesc, casó con Isabel de Perellós. ${ }^{73}$ Muy joven, se pone al servicio de Alfonso V con ocasión de su primera expedición italiana en 1420. Allá presta excelentes servicios en todas las campañas militares. Destacó por sus hazañas en el sitio de Bonifacio y en Nápoles. ${ }^{74}$ Durante

68 SÁIZ, J., Caballeros del rey. Nobleza y guerra en el reinado de Alfonso el Magnánimo, Valencia, 2008, p. 367.

69 En 1392, Rodrigo Ruiz de Corella capitanea varias compañías en Cerdeña. (ZURITA, X, 52, p. 769).

70 ZURITA, X, 44, pp. 740-741. Parece que Zurita saca la noticia de TOMICH, Pere, Històries e conquestes dels reys d'Aragó e comtes de Catalunya, Barcelona, 1534 [Valencia, 1970], fol. XLIX.

71 ACA, RC, reg. 2.204, ff. 125v-126r.

72 PONS ALÓS, V., «El testamento nuncupativo del conde Corella: la solemnidad de un privilegio», Alberri. Quaderns d'investigació del Centre d'estudis contestans, (Cocentaina), 10 (1997), pp. 99-100: el tutor asignado a su hijo Eximèn por Isabel Lançol, en su testamento otorgado en 1410, en Gandia, fue su hermano Joan Lançol.

73 VICIANA, M. de, Libro segundo de la crónica de la inclita y coronada ciudad de Valencia $y$ de su reino, [Valencia, 1564], ed. a cura de Joan Iborra, Valencia, 2013, pp. 263-266; FULLANA MIRA, L., Historia de la villa y condado de Cocentaina, Valencia, 1920, pp. 261-265. GARRIDO I VALLS, Josep-David, «El difícil veïnatge d'Elx i Crevillent amb el comte de Cocentaina», La Rella. Anuario del Institut d'Estudis comarcals de Baix Vinalopó (Elche), 20 (2007), p. 156, sin citar la fuente, afirma que una hija de Eximèn Pérez de Corella casó con Lluís Cornell, gobernador de Orihuela.

${ }^{74}$ ZURITA, XIII, 8 y 9, pp. 549 y 583. 
el viaje de vuelta, Corella tuvo una destacadísima y valerosa actuación en el asalto a Marsella. ${ }^{75}$ Esta prolongada proximidad al monarca le permitió ganar la confianza del joven soberano, cuatro años mayor que él. En 1424, sus múltiples servicios le permitieron obtener del rey un privilegio para la construcción de una acequia en su lugar de Pardines. ${ }^{76} \mathrm{Y}$ ya en 1425 , Eximèn Pérez de Corella desempeña un encargo delicado para el Magnánimo, como fue asegurar el tratado con el rey de Castilla para la liberación del infante don Enrique. ${ }^{77}$ En 1429, Corella fue nombrado gobernador del reino de Valencia, cargo desde el cual se promocionó a magistraturas aun más altas de la Corona, lo que le permitió mejorar su patrimonio. ${ }^{78}$ En 1431, compró a Pere de Rocafull el lugar de Petrer con su jurisdicción criminal. ${ }^{79}$ Recuperaba así el antiguo solar valenciano de los Corella. Quizá fuera una operación de autoestima personal y familiar, una forma de reivindicar la antigüedad de su linaje.

La fortuna de Corella se labró sobre los despojos de la Cámara de la reina Violante, sobre la cual también tenía sus aspiraciones Pero Maça de Liçana, como hemos visto. Desde 1383, las villas de Asp, Elda y Novelda formaron parte de la Cámara de la reina Sibília, cuarta esposa de Pedro IV; después, se habían integrado en la de la reina Violante. Asp y Elda fueron vendidas en 1424 a Eximèn Pérez de Corella y al secretario real Francisco de Arinyo, proindiviso. ${ }^{80}$ También la villa de Cocentaina se había integrado en la Cámara de la reina Sibília de Forcià por donación del rey. Muerto el Ceremonioso, Cocentaina se asignó a la Cámara de la esposa de Juan I, la reina Violante, que la poseyó, con algunas dificultades, hasta su muerte en 1431, momento en el cual se reintegró a la Corona. En 1438, la villa fue vendida, con carta de gracia, a Joan de Próxita, en garantía por las fuertes sumas que había prestado al rey. Recuperada por la Corona en 1446, fue nuevamente empeñada a la ciudad de Valencia. ${ }^{81}$ En agosto de 1448, el rey vendió la baronía de

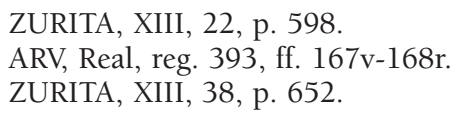

ZURITA, XIII, 22, p. 598.

ARV, Real, reg. 393, ff. 167v-168r.

ZURITA, XIII, 38, p. 652.

MATEU IBARS, J., Los virreyes de Valencia cit., pp. 89-90; RYDER, A., El Reino de Nápoles en la época de Alfonso el Magnánimo, Valencia, 1987, pp. 82-84.

79 ARV, Real, reg. 495, ff. 504r-511r.

80 FERRER I MALLOL, M. T., Les aljames sarraïnes de la Governació d'Oriola en el segle XIV, Barcelona, 1988, pp. 31-42. La compra de Asp y Elda y otros privilegios concedidos por Alfonso V a Corella, publicados por FULLANA, L., Historia cit., pp. 261 y ss. El instrumento de venta otorgado por la reina Violante en 1424 en ACA, RC, reg. 2.036 , ff. 30r-33v, y 34r-37v. La aprobación de Alfonso $\mathrm{V}$ a la venta que la reina hizo a Corella y a Arinyo de los lugares de Elda y Asp, con la jurisdicción civil y criminal, en ACA, RC, reg. 2.920, ff. 102r-110r; también en ARV, Real, reg. 495, ff. 474v-494r.

FULLANA MIRA, L., Historia. cit., pp. 181 y ss. 
Cocentaina a Eximèn Pérez Roís de Corella ${ }^{82}$ con el mero y mixto imperio, y le otorgó además el título de conde de Cocentaina, en atención a sus servicios prestados en las guerras de Italia y Norte de África. ${ }^{83}$ Para expedir este último documento se empleó el sello de oro, usado en contadas ocasiones para documentos muy solemnes, ${ }^{84}$ lo que es buena muestra del aprecio del soberano por su servidor ("plurimum dilectus», le llama en el documento de venta de Cocentaina). ${ }^{85}$ Un año antes, en 9 de septiembre de 1447, el rey le había vendido con carta de gracia el lugar de Dosaigües, que había pertenecido a Ramon de Vilaragut. ${ }^{86} \mathrm{Su}$ prestigio por entonces es grande: en 1448, en manos de su hijo, Joan Roís de Corella -bastardo, en opinión de Zurita ${ }^{87}$ - había prestado homenaje nada menos que el rey de Navarra al almirante don Fadrique y otros sobre sus pactos con Murcia en contra del condestable Álvaro de Luna y del adelantado Pedro Fajardo. ${ }^{88}$

Con la concesión de un título nobiliario, Eximèn Pérez de Corella culminaba su carrera de servicios y de promoción social. En la Corona de Aragón, los títulos condales habían estado vinculados a personas de sangre real desde los tiempos de Jaime II. Después, el único título concedido a la nobleza valenciana a individuos no pertenecientes a la familia real había sido el de vizconde de Vilanova y Xelva en 1390. En 1438 se había otorgado el de conde de Dénia al conde de Castro, para compensarle de las represalias sufridas en su patrimonio de Castilla. En 1445, Alfonso V había dado el título de conde de Aversa en Italia a Nicolau de Próxita, y el de conde de Almenara a su padre Joan de Próxita en 1447; ${ }^{89}$ en 1449, el de conde de Oliva a Francesc Gilabert de Centelles. ${ }^{90}$ A mediados del siglo XV, del grupo de barones se desgajaron unas pocas familias tituladas, una gran nobleza de rancio abolengo que no estaba unida por lazos de sangre a la dinastía (como los Lladró de Vilanova, Próxita, Centelles, además de los Mendoza, Sandoval, Vilaragut, Cardona,

82 ARV, Real, reg. 269, ff. 127r-128r; y reg. 495, ff. 432r-474r; y ACA, RC, reg. 2.943, ff. 30v-37r. También FULLANA MIRA, L., Historia cit., pp. 253-254, 276-291, y XXIVXXXVII.

83 ARV, Real, reg. 257, f. 142r.

84 ARV, Real, reg. 257, f. 143r.

85 ACA, RC, reg. 2.943, f. 30v.

86 ACA, RC, reg. 2.943, ff. 26v-30r.

87 ZURITA, XVIII, 61, p. 739, pero quizá confunda este hijo legítimo con alguno de los diez bastardos que tuvo Corella y que fueron todos legitimados por el rey en 1459 (SÁIZ, J., Caballeros cit., p. 367).

88 ZURITA, XV, 54, p. 407.

89 SAN PETRILlO, Barón de, «Los Próxita y el estado de Almenara», Anales del Centro de Cultura Valenciana, V (1932), núm. 13, p. 134.

90 ARV, Real, reg. 258, f. 16v. 
Pallars, Ruiz de Lihori). ${ }^{91}$ Entre ellos, y merced a sus especiales servicios al rey, se había conseguido introducir Eximèn Pérez de Corella, cuyo ennoblecimiento se remontaba solo a una generación atrás.

\section{DECADENCIA DE LOS MAÇA}

De este proceso de formación de una alta nobleza titulada -que tanto futuro habría de tener en la España moderna- estaban siendo excluidos los Maça de Liçana, pese a que su punto de partida -por antigüedad, prestigio y nivel de fortuna- era muy superior al de los Corella. De su modesta posición inicial, Corella, señor de Pardines (con 80 fuegos, según una estimación de la población de los lugares del brazo militar hecha en 1430), había pasado a ser señor de Elda y Asp (con 135 y 200 fuegos, respectivamente) en 1424, a los que sumó el lugar de Petrer en 1431 (36 fuegos), Dosaigües en 1447 (60 fuegos) y Cocentaina en 1448 (450 fuegos): a mediados del siglo XV, en sus dominios se contaban cerca de 1.000 fuegos. ${ }^{92}$ Corella había conseguido constituir en el sur uno de los más grandes estados señoriales del reino de Valencia, hasta entonces casi todos ellos en manos de miembros de la familia real.

Frente a la prosperidad de Corella, Pero Maça, señor de Moixent (87 fuegos), Novelda (126 fuegos), Xinosa y Monòver (con 68 fuegos, entre ambos) y del castillo La Mola (lo que sumaba un total de 281 fuegos en sus señoríos), atravesaba, pese a su gran poder, una época de dificultades económicas, común a otras grandes familias. Sabemos que su hijo Luis Cornell era señor de Alcàntera en 1433 y que en 1439 pudo comprar Alberic ${ }^{93}$ (con 140 fuegos), pero esta baronía había sido vendida ya muy endeudada por los herederos de su anterior propietario, Ferrando Ximénez d'Arenós ${ }^{94}$ A pesar de esta adquisición, en muy pocos años, sus dominios habían pasado a ser considerablemente inferiores a los de Corella.

91 PASTOR I FLUIXÀ, J., «Nobles i cavallers al País Valencià», Saitabi, XLIII (1993), p. 24: hasta 1470, no se produjo la concesión de un nuevo título, el marquesado de Elche.

92 Cfr. LÓPEZ RODRÍGUEZ, C., Nobleza y poder político en el Reino de Valencia (14161446), Valencia, 2005, pp. 100-101; y SÁIZ, J., Caballeros cit., p. 311, que estima las rentas de sus señoríos hacia 1425 en unos 40.000 s. anuales.

93 FRANCO SILVA, A., «La herencia patrimonial del Gran Cardenal de España D. Pedro González de Mendoza», Historia. Instituciones. Documentos, IX (1982), pp. 463-466. La venta con carta de gracia de la jurisdicción sobre Alberic, La Foia y Benifaraig se realizó el 14 de septiembre de 1441, por precio de 300 ducados (ACA, RC, reg. 2.774, ff. 150r-151v), confirmada en 1445.

94 LÓPEZ RODRÍGUEZ, C., Nobleza cit., pp. 97-98. Las deudas pesaban sobre las rentas de Alcàntera desde que en 1420 su propietario de entonces, Francesc de Soler, vendiera censales por 7.000 s.r. para socorrer al infante don Enrique (ARV, Gobernación, reg. 2.243 , m. 1 , ff. 45 r y ss.) 
Con frecuencia, a Pero Maça le agobiaron las deudas y estuvo amenazado por el impago de censales y las correspondientes ejecuciones judiciales de sus bienes, ${ }^{95}$ hasta el punto de que en 1431 el rey tuvo que intervenir dictando unas interesantes disposiciones para afrontar el pago de censales a sus acreedores. ${ }^{96}$ Aunque estos obtuvieran mandatos judiciales contra Maça, al ubicarse sus señoríos en la gobernación de Orihuela, presidida por el propio Maça, las ejecuciones no llevaban a término, como le ocurrió a la mujer de Jaume de Vilaragut, nieta y heredera de Pere Soler. ${ }^{97}$ En parte debido a sus problemas económicos, que tanto contrastaban con su orgullo, su pasado glorioso y su poder territorial, los Maça de Liçana fueron una familia conflictiva y violenta en sus relaciones con los oficiales reales ${ }^{98} \mathrm{y}$ con otros nobles. ${ }^{99}$ Ya conocemos el genio vivo de este caballero, que hizo alarde de su bravura desde bien joven. Pere Maça acudía con facilidad a su espada para resolver sus problemas. Le debía parecer el método más expeditivo y acorde con su tradición familiar. Muchas veces aparece secundado por su hermano natural Francesc Maça, señor de Bicorp, siempre muy activo durante las reuniones de Cortes, pues en su caso refuerza su carácter indómito, tan propio de la familia, con el particularismo de ser uno de los pocos señores valencianos poblados a Fuero de Aragón. ${ }^{100}$

El apellido Maça de Liçana aparece una y otra vez ligado a los desódenes públicos de aquellos años, liderando a otros nobles en disputas de carácter privado. Son muy numerosos y solo citaremos algunos casos sonados. En

95 En 1419 (ARV, Real, reg. 30, f. 64r-v); en 1424 (reg. 264, ff. 11v-12r); en 1434 (reg. 264, ff. 1v, 3v-4r, 20v, 40v-41r); en 1437 (reg. 65, f. 100r); en 1440 (reg. 83, ff. 2lv22r; y reg. 82, ff. 34v-35r); en 1441 (reg. 83, ff. 62v-63r), por ejemplo. En 1444, las deudas de Maça sólo con Felip de Claramunt por impago de pensiones de censales ascendían a 27.000 s.r. (más 10.000 s.r. de penas y gastos), para cuya satisfacción se subastaron sus bienes muebles y semovientes, rentas y derechos en Novelda, Xinosa, Monòver y La Mola. (ARV, Real, reg. 85, f. 174r-v). En 1445, las pensiones impagadas por Maça y Luis Cornell a Jaume Yvanyes de Riudolins ascendían a 21.000 s.r. (ARV, Real, reg. 86, ff. 24r-25r).

96 ARV, Real, reg. 45, f. 134v.

97 ARV, Real, reg. 85, f. 55r-v; reg. 47, f. 94; reg. 261, ff. 136v-137v; reg. 269, ff. 45r-v; Gobernación, reg. 2.805, m. 1, f. 1r.

98 Cabe citar, por ejemplo, la reacción de Pero Maça de Liçana en el caso de un vasallo musulmán huido a Castilla y apresado por el lugarteniente de gobernador de Orihuela en 1432 (ARV, Real, reg. 50, f. 61r).

99 Las disputas entre los Maça de Liçana y los Próxita o los Boill Lladró, en LÓPEZ RODRÍGUEZ, C., «Guerras privadas nobiliarias y paz pública en el reino de Valencia (1416-1458)», en $\mathrm{M}^{a}$ Isabel Loring García (ed.), Historia social, pensamiento historiográfico y Edad Media. Homenaje al Profesor Abilio Barbero de Aguilera, Madrid, 1997, pp. 643-667.

100 Por ejemplo, durante las Cortes de 1443-46, en AMV, yy 17, ff. 115v y 364r-365r. 
1421, el síndico del brazo militar protestó en nombre de su estamento ante el gobernador del reino contra el arresto que había ordenado de varios caballeros para que «no puxan anar e valer al noble don Pero Maça de Liçana». ${ }^{101}$ En 1424, Alfonso V impuso treguas en los desafíos dados por Francesc Maça a mossèn Ramon Boill, a Joan Pujades, y a micer Guillem d'Alpicat. ${ }^{102}$ En abril de 1427, Pere Boïl Lladró desafió a su concuñado Pero Maça y a Luis Cornell, porque no le pagaban ciertas cantidades que se le adeudaban por la ocupación de lugar de Figueroles. ${ }^{103}$ Muy sonado fue el caso surgido en 1436 por la herencia de Galceran de Vilarig, casado con Yolant Lançol, entre su única hija Yolant y el poderoso Jaume d'Aragó, señor de Arenós. Se disputaba la posesión de los castillos de Cirat, Pandiel y El Tormo. Pero Maça de Liçana intervino junto a Galcerà Castellà, Pere Lladró, Guerau Bou, «com a parents e coniunctes persones», con Luis de Calatayud, como tutor de la heredera Vilarig, frente a las pretensiones de Jaume d'Aragó. A pesar de las disposiciones dictadas por la Audiencia real, en marzo de 1439 estos lugares estaban ocupados por Jaume d'Aragó, razón por la cual algunos amigos y parientes de la heredera se aprestaban a acudir a vías más expeditivas. ${ }^{104}$ En noviembre de 1439 Jaume d'Aragó acusó a Pero Maça de Liçana de haber tomado las causas de la Vilarig como cosa suya; los oficiales que intervenían, entre ellos Gabriel de Palomar, eran del partido de Maça, de quien se sostenían, a quien prestaban dinero y quien les defendía con la espada en la mano cuando hacía falta. ${ }^{105}$

\section{PRIMERAS CONFRONTACIONES (1417-1429)}

¿Por qué Pero Maça de Liçana había llegado a esta tesitura? Desde la Conquista y más aún desde los tiempos de la Unión, los Maça de Liçana habían

101 ARV, Gobernación, reg. 2.227, m. 16, f. 15r.

102 Ordenaba además al gobernador no ayudar a ninguno de los combatientes, prenderlos e informarle de todos los oficios, beneficios y otras rentas reales de las cuales gozaran Maça o sus valedores, a quienes amenazó con privarles de ellas y de sus lugares de Millars y Otavell para que sirviera de escarmiento (ARV, Real, reg. 232, f. 100r). El rey conminó a Francesc Maça a suspender sus desafíos y le notificó que había dispuesto que los retados por él fueran favorecidos por sus oficiales (ARV, Real, reg. 32, f. 80r). La Cancillería escribió a los jurados de Valencia, para tranquilizarlos y comunicarles que el rey ya había tomado medidas (ARV, Real, reg. 232, f. 100r-v; y reg. 32, f. 80r). En junio, Maça accedió a dejar los hechos en poder del monarca: los pleitos con Boïl se debían al desempeño de la procuración del condado de Luna (ARV, Real, reg. 232, f. 108r).

103 RIQUER, M. de, Vida cit., pp. 107-108.

104 ARV, Real, reg. 70, f. 4v; LÓPEZ RODRÍGUEZ, C., Nobleza cit., pp. 175-178.

105 ARV, Gobernación, reg. 2.804, Lletres reials, ff. 2v-3r. Y, sin embargo, unos pocos años antes, Jaume d'Aragó y Francesc Maça habían sido aliados: cfr. nota 165. 
estado siempre al servicio del rey. Durante el Interregno, acaso por la proximidad de sus señoríos a la frontera con Castilla, Pero Maça de Liçana había militado en las filas trastamaristas, lideradas por los Centelles, pese a los cambios ocasionales de bando. Incluso dirigió algunas operaciones militares y golpes de mano contra los urgelistas. Acabado el Interregno, perteneció al consejo real durante el sitio de Balaguer en 1413, donde destacó por su esfuerzo y valor, e intervino como interlocutor del conde de Urgel para tratar la paz, sin resultado. ${ }^{106}$ En recompensa, en 1414 Fernando I le otorgó el lugar de Albalat de Cinca, confiscado a Jaume d'Urgell. ${ }^{107}$ Sin embargo, Maça no debió sentir suficientemente bien retribuida su entrega a la dinastía. Riquer cita una carta de Joan Mercader, baile general de Valencia, escrita al rey en 1413, en la cual le hace saber que encontraba un poco excesivo el hecho de que a Bernat Centelles se le hubiera dado un sueldo de doscientos cincuenta rocines y a Pero Maça sólo de cien. ${ }^{108}$ Durante las Cortes de 1417 se pasó nuevamente al bando de los Vilaragut, del que se convierte en uno de sus cabecillas. ${ }^{109}$ Este bando protestaba contra su exclusión de los puestos del gobierno del reino, en parte a causa de la antigua militancia urgelista de muchos de sus seguidores. En esas filas coincidió con Corella, cuya posición pública todavía era más bien secundaria. Eso cambió pronto, porque Corella debía ser un joven brillante y ambicioso. Ya durante las siguientes Cortes de 1419, fue elegido uno de los cuatro miembros militares designados para discutir la oferta al rey, la cual fue rebajada de 60.000 a $40.000 \mathrm{fl} .{ }^{110}$ Por el contrario, Maça aparece retraído de la actividad política durante estas Cortes. Acaso se debiera a uno de sus accesos de mal genio: en septiembre de 1418 había intercambiado cartas de batalla con el bastardo Joan de Vilaragut por motivos que no son muy claros, si es que los hubo. ${ }^{111}$ Es notable que, con Maça apartado de la primera fila, la nobleza actuara sin divisiones.

Concluida esta asamblea, Corella pasa con el rey a Italia, ${ }^{112}$ sin mostrar las reticencias que tanto irritaban al soberano. Por el contrario, Maça, aunque en 1419 había obtenido un guiaje para ir al servicio armado de su señor en su viaje a Sicilia y Cerdeña, ${ }^{113}$ regresa pronto a sus posesiones ibéricas. A su

\footnotetext{
106 ZURITA, XII, 21, 26 y 27. Sobre su actuación durante el sitio de esta villa, SÁIZ, J., Caballeros cit., p. 240 , n. 54.

107 RIQUER, M. de, Vida cit., pp. 61-63.

108 RIQUER, M. de, Vida cit., p. 61.

109 Según el proceso de estas Cortes conservado en ARV, Real, reg. 509.

110 ARV, Real, reg. 511, ff. 13v-17r.

11 RIQUER, M. de, Vida cit., pp. 67-80, que las publica.

112 El salvoconducto real a favor de Corella par ir en servicio de armas a Cerdeña y Sicilia en 1419, en ARV, Real, reg. 35, f. 62r-v.

113 ARV, Gobernación, reg. 4.378, m. 3, f. 13r.
} 
vuelta, y mientras el rey está ausente, Maça parece recuperar su iniciativa. En las Cortes de 1421, el brazo militar le nombró como uno de los dos barones que en compañía de dos caballeros habían de representarlo en la comisión encargada de estudiar la reforma monetaria. ${ }^{114}$ Es significativo que, junto con otros tres nobles, fuera designado por el brazo militar en la comisión que debía ir ante las Cortes de Cataluña y Aragón, para que los tres reinos enviaran una representación al Magnánimo con el ruego de que regresara a sus reinos hispánicos. ${ }^{115}$ Pese a este distanciamiento, Maça actúa según las normas del código de honor caballeresco: por entonces, acoge en su castillo de La Mola y en Novelda a la infanta Catalina, fugitiva de Castilla, a la cual acompaña galantemente con su gente de armas hasta Valencia. ${ }^{116}$ Precisamente por causa de la infanta, entre otras razones, sostendría los desafíos del señor de Almazán en 1424, en los cuales estuvo muy implicado Alfonso $\mathrm{V}^{117}$ En octubre de 1422, pasa a Nápoles, a entrevistarse con su soberano por asuntos de la infanta (y no por el servicio militar al monarca, lo cual es digno de atención). El rey lo despacha y Pero Maça está de regreso en Valencia en marzo de 1423, ${ }^{118}$ unos meses antes de que estallara la sublevación de Nápoles contra el Magnánimo, durante la cual tan buenos servicios prestó Corella, que tanto destacó además por su valor en el asalto a Marsella en el viaje de regreso. ${ }^{119}$ Muy al contrario, ninguna gloria pudo sacar de la primera expedición italiana Pero Maça, a pesar de su fama militar y pese a que en 1424 era, junto con Aimeric de Centelles, nada menos que mayordomo del rey. ${ }^{120}$ No obstante, su posición es tal que en 1425 interviene por orden de su señor ante el rey de Castilla en la liberación del infante Enrique, ${ }^{121}$ asunto en el cual, no lo olvidemos, prestó Corella sus primeras armas diplomáticas. Ese mismo año, Maça es beneficiario de unas cartas de recomendación del monarca dirigidas al justicia y jurados de Alicante para que le ayudaran contra cualquier enemigo (convocando la hueste local si era necesario), ${ }^{122}$ a las cuales siguió un seguro real de su persona, la de su mujer y la de sus bienes contra todas las acciones civiles iniciadas por sus deudores. ${ }^{123}$ No por

114 ARV, Real, reg. 231, ff. 46r-48v.

115 AMV, yy 9, ff. 6lv-66v.

116 ZURITA, XIII, 14

117 ZURITA, XIII, 14 y 31; RIQUER, M. de, Vida cit., pp. 83-103.

118 Crónica de Pero Maça, (ed.) J. Hinojosa Montalvo, Valencia, 1979, pp. 49-50.

119 ZURITA, XIII, 22, p. 598.

120 ARV, Bailía, lib. 1.146, ff. 147r-148r. Los servicios militares de Maça entre 1420 y 1425, en SÁIZ, J., Caballeros cit., pp. 240-242, n. 55 y 56.

121 ZURITA, XIII, 38, pp. 652-653.

122 ARV, Real, reg. 32, ff. 168v-169r.

123 ARV, Real, reg. 394, ff. 57v-58r. 
eso desapareció su actitud levantisca, que tanto molestaba al Magnánimo. Además de otros bandos que ya hemos reseñado, hacia noviembre de 1424, Maça estaba en guerra con Pere de Rocafull, a quien había robado algunos bienes. El monarca no estaba dispuesto a admitir esta situación, «car jatsia en tots temps entre nostres sotmesos sia cosa perillosa guerrejar e bandolejar, ara ho és molt més, e açò per rahó dels grans affers que tenim entre mans, per la qual rahó no donariem paciència en alguna manera a tals ne altres novitats sens digne càstich». ${ }^{124}$

Por estas razones, Maça va alejándose del favor y servicio del rey en la misma o similar medida en que Corella va aproximándose hasta convertirse en un hombre de la máxima confianza del Magnánimo. Hemos visto cómo, desde su regreso de Italia en diciembre de 1423, Alfonso V favoreció a Corella, que ejerce el cargo de coper en la Casa real. Sus primeros privilegios datan de 1424. La adquisición de Asp y Elda le dieron una relevancia y un poder que chocaba con el de su vecino Maça, ya bien asentado en sus señoríos del sur del reino y con aspiraciones sobre las posesiones de la cámara de la reina Violante, las cuales veía cómo pasaban, por efecto de las influencias políticas, a su nuevo rival. Hasta cierto punto, estas rivalidades estaban fomentadas indirectamente por el propio rey, quien actualizaba así un status quo que databa de muchos años atrás, al sustituir la relación que los anteriores monarcas habían establecido con la familia noble dominante en la zona por otra de nuevo cuño. Sin embargo, Maça, aún con dificultades económicas y retraído del servicio al soberano en su política exterior, gozaba de un poder personal grande, lideraba un sector destacado de la nobleza regional y su posición en el sur del reino (en circunstancias muy delicadas y en vísperas de la guerra con Castilla, en cuya frontera tenía situados sus señoríos, con una situación estratégica clave) era todavía muy firme. Tanto que Pero Maça tuvo ocasión de aumentar su poder.

En 1416, Olfo de Próxita, uno de los barones valencianos más importantes, renunció al cargo de gobernador de Orihuela. Para sustituirle, el rey nombró a un caballero, Antic Almugàver. ${ }^{125}$ Le sucedió otro caballero, Lluís de Vilarasa. A su muerte, el rey nombró de forma vitalicia, el 8 de marzo de 1427, a Pero Maça de Liçana como gobernador ultra Sexonam (distrito donde se situaban sus señoríos), movido por su fidelidad y los múltiples servicios prestados al rey Fernando. ${ }^{126}$ Con este nombramiento, parecía que se respetaba el orden natural de la jerarquía nobiliaria, pues el cargo daba a Maça,

\footnotetext{
124 ARV, Real, reg. 232, f. 113v.

125 ARV, Real, reg. 418, ff. 15v-16r.

126 ARV, Real, reg. 418, f. $84 \mathrm{v}$.
} 
barón de rancia estirpe, cierta preeminencia formal, basada en el ejercicio de un oficio público, sobre Corella, un caballero recientemente ennoblecido que aspiraba a ampliar sus dominios en el área de influencia que Maça podía considerar como suya. Si el monarca creyó que así domaría al bravo aristócrata se equivocó. Maça no esperó mucho tiempo para aprovecharse de su puesto -lo que es indicativo de su carácter y aspiraciones-, por lo que los conflictos no tardaron en estallar. A fines de 1427, Maça, como gobernador de Orihuela, amenazaba con proceder «ab mà rigorosa» contra oficiales y vasallos de la villa de Elda, del noble Eximèn Pérez de Corella, que se habían negado a dar respuesta de algunos almogávares de Granada perseguidos por Maça. ${ }^{127}$ El 18 noviembre encabezó una expedición con gente armada hasta Elda para apresar a un musulmán acusado de actuar como almogáver, un tal Çintar: la violenta reacción de la población le obligó a huir de un modo no muy honroso ni acorde con su prestigio. Cuando preguntó a los amotinados: «no conexeu que yo són vostre governador?», la muchedumbre en armas le contestó: «no conexem governador ni rey, sinó a mossèn Corella!». Volvió una semana más tarde con una hueste más nutrida, para talar la huerta de Elda y ocupar la población en nombre del rey. ${ }^{128}$ Corella consiguió en diciembre de 1427 que le fueran retornados la villa y castillo de Elda y por añadidura obtuvo unos escritos reales que le sustraían a la jurisdicción de su rival. ${ }^{129}$ Unos meses más tarde, las tornas se invertían. En febrero de 1428, fueron los hombres de Maça los que entraron en Asp, señorío de Corella, y robaron un jubón y una túnica a un sarraceno que encontraron arando. Este pobre campesino pudo huir y narrar lo sucedido al baile de Asp, quien al punto marchó en compañía de varios hombres hasta el límite con Novelda, lugar de Maça. Allí le salió al encuentro el alcaide del castillo de La Mola, señorío de Maça, con unos 200 o 300 hombres armados. En la brega, murieron dos vasallos de Corella. Inmediatamente, el rey ordenó al baile general abrir una investigación. ${ }^{130}$ Las luchas entre ambos nobles a través de sus vasallos alteraban la estabilidad del reino, más aún en la lejana frontera meridional (que disfrutaba en la práctica de una amplísima autonomía) y en fechas próximas

127 ARV, Real, reg. 35, f. 88v.

128 El proceso que se suscitó a raíz de estos acontecimientos, en ARV, Bailía, Apéndice, lib. núm. 83. Ha sido dado a conocer y estudiado por PONSODA LÓPEZ DE ATALAYA, S., y SOLER MILLA, J. L., «Violencia nobiliaria en el sur del reino de Valencia a fines de la Edad Media», Anales de la Universidad de Alicante. Historia medieval, 16 (2009-2010), pp. 319-347.

129 ARV, Real, reg. 42, ff. 97v-98v; reg. 43, f. 15r. Con esta misma fecha, las causas de Corella, su mujer, familiares y vasallos pasaron, por orden del rey, a ser comisionadas al baile general ultra Sexonam (ARV, Real, reg. 43, f. 15r-v).

130 ARV, Real, reg. 42, f. 122r-v; reg. 233, ff. 17v y 18v; reg. 35, f. 97v. 
a la guerra con Castilla, de tanto interés para la política dinástica de Alfonso V. La rápida intervención real siguió dos vías de actuación: impuso treguas entre los contendientes, y se interpuso como «arbitre arbitrador e amigable composador» mediante el envío de comisarios para departir los términos y amojonarlos, ${ }^{131}$ acción que no consiguió erradicar las discordias, ante lo cual en octubre el rey prorrogó las treguas por un año más. ${ }^{132}$

La situación era fuente constante de conflictos, porque tanto Asp y Elda como la baronía de Cocentaina estaban situados en la gobernación de Orihuela, a cargo de Pero Maça de Liçana, primero, y de su hijo Luis Cornell más tarde, de modo que muchas causas civiles y criminales de los Corella pasaban a resolverse ante el tribunal de esta gobernación, presidido por los Maça. Pero ya en la primavera de 1428, a consecuencia sin duda de los conflictos sostenidos con Corella y por influjo directo de este caballero, el rey privó a Maça de su cargo hasta el otoño de 1429. ${ }^{133}$ Esta enemistad personal y la rivalidad territorial no se trasladaron todavía a la vida política con ocasión de las Cortes de 1428. En ellas, Corella fue uno de los tractadors elegidos por los barones, pero -es de destacar- como procurador de la reina Violante, de cuyo patrimonio se estaba lucrando. También lo fue Pero Maça de Liçana, a título propio, lo que es revelador de su arraigo entre la nobleza del país. ${ }^{134}$ Su hermano Francesc Maça fue uno de los cuatro barones elegido como tractadors del brazo militar cuando las Cortes se mudaron de Valencia a Morvedre. ${ }^{135}$ Gracias a su actuación, los Maça pudieron introducir algunos agravios particulares contra la intromisión de los oficiales reales -sobre todo del gobernador- en las jurisdicciones señoriales del propio Francesc Maça (agravio 17) y de Pero Maça de Liçana y su señorío de Moixent (agravio 26). ${ }^{136}$ Pese a ello, las Cortes se desarrollaron sin divisiones del brazo militar.

Los problemas entre estos nobles se reprodujeron en los años siguientes. Cada uno acudió a los recursos a su alcance: Maça a la fuerza, ${ }^{137}$ y Corella a sus influencias. ${ }^{138} \mathrm{Y}$, finalmente, a las puertas de la guerra con Castilla, el 18 de mayo de 1429, Alfonso V nombró a Eximèn Pérez de Corella, de por

\footnotetext{
131 ARV, Real, reg. 43, f. 55; y reg. 40, ff. 36r, 37r y 60r-v.

132 ARV, Real, reg. 44, f. 2r-v.

133 ARV, Real, reg. 35, f. 108r; y reg. 38, f. 44r.

134 AMV, yy 10, ff. 44r-45r.

135 AMV, yy 10, f. 99v.

136 ARV, Real, reg. 231, ff. 75r y ss., y 113r-v.

137 Hasta el punto de que los oficiales de los señoríos de Corella se resistían a que Maça ejerciera su autoridad sobre ellos, como ocurrió en 1433 (ARV, Real, reg. 50, f. 75r).

138 Por ejemplo, en 1428, consiguió, de nuevo mediante la intervención del Magnánimo, la suspensión de una sentencia dictada en su contra por el obispo de Cartagena (ARV, Real, reg. 40, f. 55r).
} 
vida, para el cargo de gobernador de Valencia, que había quedado vacante por muerte de su anterior ocupante, el caballero Vidal de Blanes. ${ }^{139}$

\section{RIVALIDADES PERSONALES (1430-1435)}

La guerra con Castilla brindó una oportunidad a Maça para recuperar el favor real. En junio de 1430, Alfonso V convocó a los nobles valencianos para que acudieran con sus huestes, incluidos Maça y Corella. ${ }^{140}$ Sus servicios militares les fueron recompensados por el monarca con salvoconductos y otras mercedes, pues al estar las tierras de ambos señores situadas en la frontera castellana sufrieron los daños ocasionados por la contienda. La valerosa actitud de los dos nobles sirvió para asegurar el flanco sur del reino. ${ }^{141}$ Para evitar problemas, el rey eximió a Corella de la obligación de seguir la hueste del gobernador de Orihuela para ningún hecho de la guerra con Castilla, por muy arduo que fuera. ${ }^{142}$ Además de la incompatibilidad personal, había una razón de estrategia militar, que resulta de interés para valorar la diferente formación de ambos nobles: la naturaleza profesional de las tropas organizadas por Corella (similares al ejército real por el escaso peso de las redes clientelares) las hacía estructuralmente diferentes al resto de las compañías nobiliarias de la época, incluidas las levantadas por Maça de Liçana. ${ }^{143}$

Concluida la breve guerra, cada uno de ellos volvió por donde solía. En premio por la defensa de la frontera que hizo en Novelda, en 1430 Alfonso V donó a Luis Cornell los lugares de Alcàntera y Beneixida, junto con otras propiedades confiscadas a Sanxo Rodrigo, doctor en leyes, quien se había pasado al enemigo. ${ }^{144}$ Corella, por su parte, acompañó al Magnánimo en su marcha definitiva a Nápoles en 1432. Le sigue en sus campañas de Italia, donde prestó delicados servicios diplomáticos, ${ }^{145}$ que le permitieron encum-

139 ARV, Real, reg. 418, f. 98v. Con la misma fecha se nombró a su sustituto interino, con el nombre de lugarteniente de gobernador, en la persona del caballero Francesc Corts, para que ejerciera el cargo mientras durara la ausencia de Corella (ibídem, f. 100r).

140 ARV, Real, ff. 69v-70v, y 78r; ZURITA, XIII, 68 y 69.

${ }^{141}$ ARV, Gobernación, reg. 2.801, m. 3, f. 25r; Real, reg. 256, ff. 76v y 114r. Entre otras gestas, Pero Maça de Liçana derrotó ante Alicante a las tropas castellanas comandadas por el almirante don Fadrique (ZURITA, XIII, 70, pp. 769-770). De las muchas hazañas de Pero Maça, de Luis Cornell y de Corella se hizo eco la coetánea Crónica cit., pp. 57-60. También RIQUER, M. de, Vida cit., pp. 108-111.

142 ARV, Real, reg. 35, f. 142r.

143 Una detallada descripción en SÁIZ, J., Caballeros cit., pp. 170-174 y p. 400.

144 ARV, Real, reg. 256, f. 76v.

145 ZURITA, XIV, 3, 4, 16, y 61. 
brarse al gozar de la máxima confianza del monarca, hasta el punto de que el infante Fernando, hijo ilegítimo del Magnánimo, estuvo bajo su guarda y custodia. ${ }^{146}$ En 1442, fue uno de los principales y más destacado capitanes del rey en la toma de Nápoles. ${ }^{147}$ En 1445, sus servicios diplomáticos eran del más alto nivel; por ejemplo, actuó como embajador del Magnánimo ante el papa para tratar de ejecutar lo acordado en la paz de Terracina. ${ }^{148}$ Sus servicios son también financieros, pues actúa como prestamista o avalista del monarca, en circunstancias muy apuradas. ${ }^{149}$ Fue miembro del Consejo del duque de Calabria en 1447, y del propio Consejo del rey en 1449. ${ }^{150}$ Tuvo importantes encargos del soberano ante las Cortes de Zaragoza de 1452 y para tratar la paz con Castilla entre 1452 y $1456 .{ }^{151}$ Es conocida su ultima embajada ante el papa Calixto III, en 1456, y su fuerte discusión con Alfonso de Borja, a resultas de la cual murió. ${ }^{152}$ Por el contrario, ni Pero Maça, que falleció el 30 de abril de $1448^{153}$, a los 64 años de edad, ni su hijo Luis Cornell $\mathrm{u}$ otro familiar directo destacaron por sus servicios al Magnánimo en lo que este más estimaba, que fue su política italiana. ${ }^{154}$

La diferente actitud de Pero Maça y Corella queda bien reflejada en la evolución de las cantidades recibidas del monarca entre 1424 y 1432 (período durante el cual el Magnánimo permaneció en sus dominios hispánicos). En la contabilidad de la Bailía general de Valencia, ambos nobles mantienen una situación equiparable. En 1424, Maça cobró 16.500 s. r. más otros 3.300 s. de gracia real, y 33.000 s., como sueldo para gente de armas en 1425, año en el cual también se pagaron a Francesc Maça 3.300 s. por este concepto. La asignación real a Corella fue de 8.100 s. r. en 1424 y 5.765 s. como sala-

\footnotetext{
ZURITA, XIV, 35.

ZURITA, XV, 10.

ZURITA, XV, 32, 37 y 49.

Solo en noviembre de 1446, Corella, junto con otros consejeros reales, tomó 8.200 ducados en cinco letras de cambio de los banqueros Giovanni Miroballo, Pere Cimart y Nicolau Calcer (ARV, MR, núm. 8.791, ff. 20r-21r).

150 ZURITA, XV, 48 y 57.

151 ZURITA, XV, 65; y XVI, 1, 9 y 38.

152 ZURITA, XVI, 39. Eximèn Pérez Roís de Corella falleció en Nápoles el 17 de octubre de 1457, dejando como heredero universal a su hijo Joan Roís de Corella (PONS ALÓS, V., «El testamento» cit., pp. 104 y ss., que se documenta en la adveración de su testamento nuncupativo ante la Real Cancillería, conservada en ARV, Real, reg. 258, ff. 124v-130r).

153 ESQUERDO, O., Nobiliario valenciano cit., pp. 138-139.

154 Aunque RIQUER, M. de, Vida cit., pp. 115-116, sin más autotidad que la del dietario del capellán del Magnánimo, supone que Luis Cornell cayó prisionero en Ponza. Las noticias que tenemos son más tardías: nos consta que, en 1444, Luis Cornell se aprestaba para incorporarse a la armada real (ARV, Gobernación, reg. 2.806, m. 1, f. 8v).
} 
rio de su gente de armas en $1425 .{ }^{155}$ En octubre de 1424, se asentaron como entrada 4.800 s. r. y $300 \mathrm{fl}$. procedentes del impuesto de la coronación del rey en Valencia, recaudados por el baile general, pero que cobró Eximèn Pérez de Corella, coper real, por donación graciosa del monarca. ${ }^{156}$ A partir de 1429, este noble recibió 10.000 s. r. anuales de la Bailía General de Valencia, como salario por el desempeño de su oficio de gobernador, más otras ayudas puntuales: en 1432, 18.750 s. r. para armar una galera al servicio del rey, más otros 2.750 s. como gracia del monarca; ${ }^{157}$ en $1434,5.960$ s. y 4 dineros como socorro del rey en el armamento de una galera. ${ }^{158}$

El estado de cosas es diferente en las cuentas de la Tesorería general, sobre la cual el margen de maniobra del rey era mayor. ${ }^{159}$ Frente a los magros cobros de Pere Maça, entre julio de 1424 y abril de 1432 Corella recibió numerosos pagos de la Tesorería real, unos en concepto de gastos oficiales o devolución de pequeños préstamos hechos al rey, pero la mayoría como donativos, ayudas, socorro para el armamento de galeras y otros, que ascendieron a la cantidad de 1.970 fl., 22.994 s. b. y 141.276 s. r. El contraste es aún más brusco unos años más tarde, en 1446-47, para los cuales se han conservado los libros de cuentas de la Tesorería general del rey en Nápoles. Pere Maça de Liçana no aparece en sus asientos, mientras que Corella, mediante múltiples pagos en concepto de armamento de galeras, ayudas y donaciones graciosas, gastos oficiales o devolución de préstamos, recibió de la Tesorería al menos 2.677 ducados y 82.300 s. r. sólo durante 1446 y 1447. ${ }^{160}$ Quizá por este apoyo financiero del monarca, y al contrario de lo que pasa con Maça, las referencias a las dificultades económicas de Corella son menores, aunque las

155 ARV, MR, núms. 44 y 45.

156 ARV, MR, núm. 8.759, ff. 30v y 32v; núm. 8.760, f. 36r.

157 ARV, MR, núm. 51.

158 ARV, MR, num. 52

159 A través de esta caja se pagaron a Pero Maça $200 \mathrm{fl}$. en agosto de 1424 (ARV, MR, núm. $8.765, \mathrm{f} .87 \mathrm{r}$ ) y otros $200 \mathrm{fl}$. en agosto 1429 , en concepto de sueldo por la gente de armas movilizada para la guerra de Castilla (ibídem, núm. 8.777, f. 73r). La subvención establecida fue de $15 \mathrm{fl}$. el hombre a caballo, por lo que Maça debió aportar unos 13 rocines a la guerra. Corella percibió $540 \mathrm{fl}$. por 36 hombres a caballo (ibídem, f. 71v). A Francesc Maça se le dieron 550 s. por sus servicios en 1426 (ibídem, núm. 8.761, f. 78r); en 1427 aparece como uxer d'armes a quien el rey da 3.000 fl. de donativo como ayuda en su matrimonio (ibídem, núm. 8.767, ff. 112r y 124r) y otros $3.000 \mathrm{fl}$. en 1428 por la compra de un caballo (ibídem, núm. 8.773, f. 187r). ARV, MR, núm. 8.781. Para los pagos reales a Corella en el período 1425-1429, cfr. además SÁIZ, J., Caballeros cit., pp. 312-313. En la casa del rey estaba ya Joan de Corella, que cobraba su quitación como paje en diciembre de 1428 (ARV, MR, núm. 8.773 , f. 205r). 
tuvo, como cualquier noble de la época. ${ }^{161}$ Cuando las hay, Corella aparece más protegido aún que Maça, gracias a sus influencias. ${ }^{162}$

El alejamiento de Pero Maça de las decisiones más trascendentes, pese a su cargo como gobernador de Orihuela, del cual además fue depuesto temporalmente, es llamativo. Desde la guerra con Castilla, Eximèn Pérez de Corella aparece estrechamente relacionado con el gobierno del reino y con las decisiones más delicadas, incluidas las provisiones de oficios y las elecciones municipales y de la Diputación, en las cuales sigue las directrices del monarca. ${ }^{163}$ Por el contrario, Maça queda relegado de este núcleo de poder, recluido en sus posesiones del sur de Valencia, donde se sitúa su área de influencia. La correspondencia que le dirige el rey tiene un carácter menos confidencial y más burocrático, relativa a asuntos ordinarios y de trámite, sin tanto calado político. Su fuerte oposición a Corella tuvo una nueva escalada hacia 1435, con un espinoso asunto que se vio ante el Consejo Real de Valencia relativo a las elecciones municipales de Orihuela, cuando se presentaron ante el gobernador de Valencia los vecinos de aquella ciudad Joan Pérez de Vayello, Jaume Terres, Bernat Martí y Bertomeu Monsi, quienes acudieron por temor a Pero Maça de Liçana, que los tenía apresados en sus casas. Las persecuciones se iniciaron cuando, tras ser nombrado gobernador de Orihuela, quiso atraer a su partido a los que habían salido en las elecciones municipales, los cuales se negaron a ello. El asunto levantó grandes discusiones acerca de la primacía entre Maça (como gobernador de Orihuela) y Corella (como gobernador de Valencia y presidente del Consejo Real). Maça no reconocía ninguna superioridad a Corella, y en ello pesaban las disensiones de carácter privado que,

161 En 1434, afrontó una reclamación de dos vecinos de Barcelona por un impago de censales que ascendía a 18.788 s. r. (ARV, Gobernación, reg. 2.803, m. 4, ff. 3r y 26v).

162 Pasó, por ejemplo, en mayo de 1439, con un recurso de Pere d'Ódena ante la Audiencia real, que don Juan de Navarra evacuó al propio rey, por una causa sobre el pago de 1.000 s. censales contra la universidades y aljamas de Elda y Asp y su señor, Corella (ARV, Real, reg. 69, ff. 5v-6v).

163 A mediados de noviembre de 1430, el rey despachó en secreto con micer Gabriel de Palomar la elección del justicia criminal de la ciudad de Valencia, para que lo trasladara a Corella y al baile general (ARV, Real, reg. 233, f. 97r). El monarca ordenó directamente a Corella, al baile general y a su consejero Gabriel Palomar la nómina de quienes habrían de salir elegidos como diputados del General para el trienio siguiente, y les encargó la elección de los oficiales inferiores (ARV, Real, reg. 40, f. 198v). En 1433 el rey escribió al baile general porque había sabido que la bailía de Almassora vacaba por muerte de su último poseedor, y le mandaba informarse si le pertenecía su provisión, en cuyo caso debía nombrar a Pere Roís de Corella, «per contemplació de sos serveys» (ARV, Real, reg. 50, f. 80r). Este Pere Roís de Corella quizá pueda identificarse con uno de los hijos del gobernador que llegaría a ser arcediano de Xàtiva, protonotario del papa y consejero del rey en Nápoles (RYDER, A., El Reino cit., p. 123). 
según confesaba él mismo, le enfrentaban con Corella. ${ }^{164}$ La rivalidad entre ambos por el control de las elecciones municipales en la ciudad más importante del área de influencia de Maça se continuó con otros enfrentamientos por el control de la capital del reino.

\section{LUCHAS POLÍTICAS EN LA CIUDAD DE VALENCIA (1435-36)}

Mucho había cambiado la posición de los Maça y de los Corella: un siglo antes, los primeros habían permanecido fieles al monarca durante las guerras de la Unión mientras que los segundos habían sufrido condenas, confiscaciones y ajusticiamientos. Ahora, las tornas cambiaban, sin llegar a los excesos de entonces. No debemos minusvalorar el efecto que la memoria de las vicisitudes tan distintas de sus antecesores pudo suscitar en nuestros protagonistas. Pero los desencuentros tenían cada vez más unas razones políticas coetáneas, derivadas de su diferente posición ante el favor y el servicio real.

Con la nueva partida del rey hacia Italia en 1432, se produjo una intensa movilización de medios financieros y políticos en toda la Corona aragonesa destinada a la conquista de Nápoles, lo que alteró la estabilidad interna. La ausencia del Magnánimo relajó la disciplina del reino, tan dependiente siempre de la presencia de su soberano. Por entonces parece romperse el delicado equilibrio entre facciones nobiliarias valencianas al cual se había llegado tras los primeros años de gobierno de los Trastamaras. Desde 143334 se formaron bandos que enfrentaban a grupos de nobles, rememorando las viejas banderías de comienzos de siglo. ${ }^{165}$ En este contexto, se multiplicaron las intromisiones del gobernador Corella en las elecciones municipales para favorecer a los recomendados del rey y a sus propios partidarios. Hubo también fuertes presiones de don Juan de Navarra durante las elecciones a oficiales de la Diputación del General en diciembre de 1433. Por estos motivos, las luchas entre facciones condujeron a una situación política explosiva. La comprometida situación diplomática y política del monarca en Italia tras su derrota y prisión en Ponza (agosto de 1435) agravó las tensiones. Maça de Liçana vio entonces abrirse una puerta para desempeñar el papel en la

164 ARV, Gobernación, reg. 4.555. Tratamos el asunto en LÓPEZ RODRÍGUEZ, C., «Notas en torno al Consejo Real de Valencia entre la guerra de Castilla y la conquista de Nápoles (1429-1449)», en XV Congreso de Historia de la Corna de Aragón, Zaragoza, 1996, vol. 3, pp. 255-274.

165 Por ejemplo, las que obligaron a dictar paces entre Jaume d'Aragó, Francesc Maça de Liçana, Gabriel y Francesc Navarro, Joan de Palomar y Joan Campany con Guillem Bonet, Joan de Santacilia, Vicent Despuig, Francesc de Riusech, Joan Almenara y Joan Garriga (ARV, Real, reg. 264, ff. 16r, 217r-v; y reg. 63, f. 107r; Gobernación, reg. $3.311, \mathrm{~m} .7$, paces de 1434 , feb. 1, y 1434, mar., 22). 
escena política que debía pensar que le correspondía por nacimiento y que la pérdida del favor real le negaba.

En abril y agosto de 1435, renunciaron a sus cargos, por ese orden, Manuel y Gabriel de Palomar, racional y abogado de la ciudad de Valencia respectivamente, de quienes se había servido el Magnánimo desde 1427 para controlar la vida política de la capital. ${ }^{166}$ Sin ellos, las relaciones entre el consejo municipal y los oficiales reales empeoraron. Ya en la sesión de 15 de septiembre, tras oir cómo el baile general les trasladaba una petición de la reina para que ayudasen financieramente a la liberación de Alfonso V, el Consell de Valencia suplicó a doña María que reparase los agravios inferidos a la ciudad por los oficiales reales. ${ }^{167}$

La celebración en estas circunstancias de las Cortes no hizo más que empeorar la delicada situación, nacida, en palabras de don Juan de Navarra, «per zizànies e discòrdies dels barons e habitadors» del reino, y de las cuales se temía un renacer de «les discòrdies e bandositats antigues, les quales tant temps són stades en tant bon repòs», máxime cuando la posición internacional del rey era tan comprometida. ${ }^{168}$ La intranquilidad era tal que los hombres públicos iban acompañados de fuertes escoltas armadas, ${ }^{169} \mathrm{y}$ los incidentes menudeaban, algunos protagonizados por familiares de Corella. ${ }^{170}$ Durante la primavera y verano de 1436, los jurados de Valencia mantuvieron además una agria disputa con el gobernador por el reclutamiento forzoso de hombres para las galeras reales. Este nuevo roce se sumaba a los conflictos surgidos a raíz de las intromisiones y presiones de Corella en las elecciones municipales. ${ }^{171}$

166 CARRERES, S., Libre de memories de diversos sucesos e fets memorables e de coses senyalades de la ciutat e regne de Valencia (1308-1644), Valencia, 1930, vol. I, pp. 546547; AMV, Manuals de Consells, A-30, fols. 263v-265r; y A-31, fol. 25r. La remoción de estos oficiales había sido aceptada por el rey en marzo de 1435, en el marco de la reforma del gobierno municipal propuesto por los jurados de Valencia, e incluyó la destitución de Manuel de Palomar como síndico de la baronía de Paterna, Benaguasil y la Pobla, que ya había provocado disputas entre Francec Maça y Ramon Boïl en 1424 (ACA, RC, reg. 2.693, ff. 163v-164v). Tratamos esta cuestión en LÓPEZ RODRÍGUEZ, C., Nobleza cit., pp. 285 y ss.

167 AMV, Manuals de Consells, A-31, fol. 35v.

168 ARV, Real, reg. 64, fol. 33v.

169 ARV, Gobernación, reg. 2.257, m. 2, fol. 17r.

170 A comienzos de 1436, Pere Roís de Corella junto con su hermano Jaumot Escrivà y el hijo del gobernador, Joan Roís de Corella, hirieron al justicia criminal de la ciudad, Lluís Castellví, cuando fue a detenerlos por jugar en público a los dados (ARV, Gobernación, reg. 2.257, m. 1, fol. 24r; y m. 2, fol. 42r; Real, reg. 65, fol. 54v; reg. 64, fol. 113v; reg. 261, fol. 1r; reg. 67, fol. 169r-170r). La viuda de Lluís de Castellví denunció la agresión ante las Cortes de 1437-38 (ARV, Real, reg. 501, fols. 22r-23r).

171 ARV, Gobernación, reg. 2.257, m. 5, fols. 17r y ss; y Real, reg. 64, fols. 36v y 53v-54r; CARRERES, S., Libre cit., vol. I, p. 559. 
Las quejas de los jurados de Valencia llegaron hasta don Juan de Navarra, quien se mostró favorable a sus reclamaciones, para no empeorar el estado de cosas mientras se celebraban las Cortes generales y se habían convocado ya las particulares de Valencia. ${ }^{172}$ Los jurados acusaban al gobernador Corella de inmiscuirse en su jurisdicción e incluso en las elecciones municipales, celebradas a fines de mayo. A su vez, Corella imputó de regir «la ciutat ab tirania» a los jurados Manuel d'Exarch y Joan Dezpuig e intentó encarcelarlos sin éxito. La reacción unánime del Consell municipal abortó esta maniobra. En primer lugar, el consejo envió una embajada al rey y a don Juan de Navarra. Además, como parecía que el gobernador presionaba a los consejeros de las parroquias para forzarlos a nombrar a sus partidarios, el Consell municipal puso bajo su protección a los electores y les ordenó celebrar las elecciones mediantes el sistema tradicional de redolins. A una comisión enviada por el municipio, el gobernador le mostró órdenes escritas de don Juan de Navarra para actuar como lo estaba haciendo. Este detalle es significativo para comprender el carácter de los bandos que se habían formado y las intenciones de uno de ellos, siguiendo las directrices de la Corona, de inmiscuirse en el poder municipal. Requerido por los jurados, obligado por las difíciles circunstancias políticas, presionado también por la celebración de Cortes en los tres reinos peninsulares y la débil posición del Magnánimo en Italia, don Juan de Navarra no tuvo más remedio que recriminar al fiel Pérez de Corella, en junio de 1436, su exceso de celo en el cumplimiento de las órdenes. Paladinamente, le aclaró entonces que cuando le había recomendado que vigilase el desarrollo de las elecciones municipales, ello era sin que se derogasen los fueros y privilegios de la ciudad, que en todo momento debían cumplirse; su intervención debía limitarse a velar para que los elegidos fuesen personas suficientes para regir la ciudad. ${ }^{173}$ Parece, pues, que Corella se había excedido en la interpretación de las órdenes de la Corona, o que, en vista del cariz que tomaba la situación, el lugarteniente general rectificaba sus instrucciones. Así que las elecciones se celebraron en la forma acostumbrada. ${ }^{174}$ Una de las primeras actuaciones de los nuevos jurados fue marchar al lugar de Pardines, señorío de Corella. Allí sacaron de la cárcel a veinte hombres que el gobernador había apresado por medios poco ortodoxos con el fin de reclutarlos para su propia galera. Los galeotes fueron trasladados a la prisión de la ciudad de Valencia. ${ }^{175}$

172 ARV, Real, reg. 64, f. 54r-v.

173 ARV, Real, reg. 64, ff. 30-31. Hasta los religiosos se quejaron aquel año de las intromisiones del gobernador en sus asuntos (ARV, Real, reg. 68, ff. 48v).

174 AMV, Manuals de Consells, A-31, ff. 90r-93r.

175 AMV, Manuals de Consells, A-31, f. 111v. 
Por entonces, la concurrencia de nobles en la ciudad, venidos para asistir a las Cortes, muchos de ellos ya muy enfrentados por cuestiones personales, enrareció el ambiente político, bastante tenso por la manifiesta enemistad entre el gobernador y los jurados. ${ }^{176}$ La situación preocupó a las autoridades reales, que buscaban recaudar dinero para enviar con urgencia a Italia. Por eso, el Consejo Real trabajó para apaciguar los bandos que se estaban formando, al margen de pasiones y particulares intereses, según manifestó don Juan de Navarra. ${ }^{177}$ Pero el gobernador no cesó en sus amenazas en la recluta de hombres para su galera; tampoco respetó la concordia firmada con los jurados para la requisa de armas, e incluso continuó entrometiéndose en causas que no le correspondían. Unánimemente, el consell municipal consideró estos agravios atentatorios para el bien público de la ciudad, por lo que envió otra embajada al rey. ${ }^{178}$

A lo largo del verano, la intranquilidad fue en aumento y se sucedieron algunos episodios armados. El Consejo Real de Valencia, el propio don Juan de Navarra y los jurados de la ciudad trataron de pacificar los bandos nobiliarios, sin resultados. Finalmente, en octubre de 1436, don Juan ordenó expulsar de la ciudad de Valencia, para evitar mayores escándalos, a más de cuarenta y cinco nobles implicados en los bandos. El primero de la lista era Pero Maça de Liçana, e incluía a Luis Cornell. ${ }^{179}$ El consejo municipal de Valencia no tuvo esta vez más remedio que aceptar las órdenes de don Juan. ${ }^{180}$ Los nobles expulsados estaban involucrados en el gobierno municipal y en el de la Diputación del General, si bien don Juan había procurado mantener su imparcialidad. ${ }^{181}$ Sin embargo, aunque algunos caballeros firmaron treguas e incluso la Audiencia Real sentenció a muerte a miembros de una y otra parte, los conflcitos no desaparecieron, sino que se trasladaron a las sesiones de Cortes que se abrieron en 1437.

\footnotetext{
176 ARV, Real, reg. 64, ff. 33v, 36, 44-46; Gobernación, reg. 2.257, m. 2, f. 17r.

177 ARV, Real, reg. 64, f. 43r-v.

178 AMV, Manuals de Consells, A-31, ff. 115v-116v.

179 ARV, Real, reg. 64, ff. 64r-65r; y reg. 68, ff. 34v-35r.

180 AMV, Manuals de Consells, A-31, ff. 131v-132r. Pero la competencia sobre este asunto, especialmente delicado, provocó una nueva discusión entre el gobernador y los jurados (ARV, Gobernación, reg. 2.258, m. 15, f. 17r).

181 ARV, Real, reg. 68, f. 42v. En las elecciones de 1436 Luis Cornell fue elegido diputado segundo por el brazo militar (ARV, Generalidad, lib. 701). Desde ese año, los Maça desempeñaron cargos de importancia en esta institución, a la cual habían sido hasta entonces ajenos. Francesc Maça fue contador por el brazo militar en las elecciones de 1448; Luis Cornell fue elegido de nuevo diputado primero en las de 1451, y Francesc Maça también diputado primero en las de 1457.
} 


\section{LA OFENSIVA DE MAÇA (1437-1446)}

En este contexto, se celebraron las Cortes de Valencia de 1437-38, durante las cuales la nobleza se dividió en dos bandos u «opiniones», como no lo había hecho desde veinte años atrás. Sorprendentemente, los dos gobernadores, Corella y Maça, militaron en el mismo partido, enfrentado al liderado por los Castellví, que llegaron a presentar trece agravios contra Corella. ${ }^{182}$ Tanto Pero Maça como Corella fueron nombrados tractadors en representación del brazo militar, si bien al primero lo eligieron los nobles y el segundo lo fue por designación del lugarteniente general don Juan de Navarra, lo que es digno de reseñarse. ${ }^{183}$ Todo ello nos indica que Maça desempeñaba un cierto liderazgo entre la nobleza del país: durante la sesión plenara del 20 de agosto, en la cual las Cortes aceptaron dar a don Juan la ayuda pecuniaria solicitada, cuando algunos singulares del brazo militar protestaron contra los agravios de su mismo estamento que fueran perjudiciales a los Fueros de Aragón, el resto de la nobleza, en la persona de Pero Maça de Liçana, reclamó la unidad de los fueros a los que estaba sometido el reino de Valencia. ${ }^{184}$ De nuevo fue Pero Maça de Liçana (junto con Hug de Cardona y Gracià de Monsoriu) quien actuó como portavoz de la nobleza para protestar en defensa de sus jurisdicciones cuando, el 20 de septiembre de 1437, don Juan de Navarra proveyó el capítulo primero de los agravios del brazo real. ${ }^{185}$ Significativamente, fue Corella uno de los nobles beneficiados con los nuevos privilegios de inmunidad, franquicia y exención de los impuestos de lezda, peaje, portazgo, y otros que se promulgaron tras las Cortes de 1437-38, ${ }^{186}$ de los cuales no pudo aprovecharse Maça. Aunque sus desvelos no se vieron retribuidos (y es de suponer que eso agravararía su resentimiento), lo que nos interesa ahora de estos episodios es constatar que Pero Maça de Liçana, en ausencia del monarca, ha incrementado su actividad hasta convertirse en uno de los líderes de la nobleza, enfrentado al gobernador Corella, más que por diferencias de carácter ideológico -pues ambos militan en la misma «opinión» o bando durante las Cortes- por su pura ambición de poder e intereses personales, que reviste bajo la defensa de los fueros y costumbres del reino.

182 Los agravios del brazo militar en ARV, Real, reg. 501.

183 ARV, Real, reg. 512, ff. 125r-128r. Pere Maça y su hermano Francesc formaron además parte de las comisiones del brazo nobiliario para la recaudación del servicio y para la revisión de los agravios (ibídem, ff. 74, olim 73, y 181r-182v). 
Esta posición de Pero Maça como líder de la nobleza menos involucrada en las reformas institucionales del Magnánimo y menos interesada en su política exterior (y, por tanto, menos beneficiada de ella) se consolidó en los años sucesivos. Por su poder, mentalidad y larga experiencia política, parecía el hombre llamado a dirigir a la nobleza del país, aferrada a sus privilegios tradicionales, hasta el punto de encabezarla con vigor contra los intereses de los miembros de la familia real y sus aliados más cercanos. Durante las largas Cortes de 1443-46, lideró de nuevo uno de los bandos nobiliarios, ${ }^{187}$ en el cual se aglutinó la mayoría del brazo militar, frente al bando dirigido por Hug de Cardona, tras quien parece alistarse la nobleza más vinculada a la dinastía. Una nueva división del brazo militar se originó a propósito de la prisión de mossèn Berenguer de Saranyana, acusado del asesinato de su hermano Joan. La facción que se oponía a la reina en el modo en que trataba de resolver este asunto para despachar el fin de las Cortes estaba dirigida por Francesc Maça. En la contraria, es decir, la nobleza que apoyaba a la reina, figuraba precisamente Corella. ${ }^{188} \mathrm{La}$ «opinión» liderada por los Maça y el vizconde de Vilanova, por entonces todavía el único noble valenciano de sangre no real con un título, reaccionaba en defensa de los fueros y privilegios tradicionales del brazo contra los procedimientos innovadores empleados por doña María. Todavía a principios de 1445 Pero Maça continuaba al frente de esta bandería, que aglutinaba al grueso de los barones y de los caballeros con mayor peso político, lo que pone de relieve su capacidad de liderazgo, sobre todo entre la aristocracia de linaje más antiguo, ${ }^{189}$ hasta el punto de que ambos partidos acabaron fusionados, encabezados siempre por Pero Maça. La división de las Cortes no fue una particularidad de las valencianas. Algo parecido ocurrió en las de Aragón de 1446-50, en las cuales hubo grandes disputas. Zurita, con su habitual perspicacia, opina que había dos parcialidades: una que procuraba el beneficio del reino, y la otra el servicio del rey. ${ }^{190}$

A pesar de que la posición de Maça era sólida, si juzgamos por su papel en las sesiones de las Cortes de aquellos años, no puede compararse con el encumbramiento de su mayor rival político y personal, Eximèn Pérez de

\footnotetext{
187 Se formó al elegir a los examinadores de agravios (AMV, yy 17, ff. 60r-73r).

188 AMV, yy 17, ff. 165r-189r.

189 AMV, yy 17, ff. 280v-281r. Justo antes de la clausura de las Cortes, Pero Maça lideró una nueva «opinión» nobiliaria contraria a la promulgación de la llamada «pragmàtica o fur dels censals», incluida bajo la rúbrica XX en la colección de Palmar publicada en 1482, en defensa de las costumbres de la tierra (AMV, yy 17, ff. 359v363r). En estas Cortes, Luis Cornell fue nombrado tasador del brazo militar para repartir entre sus miembros la ayuda aprobada a favor del monarca (ibídem, yy 17, ff. $381 v-382 v)$.

190 ZURITA, XV, 69, pp. 426-429.
} 
Corella. Ninguno de los dos se benefició de las licencias para imponer sisas concedidas al concluir las Cortes por don Juan de Navarra a favor de muchos nobles. Es comprensible que la Corona no premiara a Maça por su actitud obstruccionista. En cambio, estas licencias no le hacían mucha falta a Corella, que fue de sobra recompensado. Como vimos, al acabar las Cortes de 1446 se hizo con las baronías de Dosaigües y Cocentaina y con el título condal. Entre 1438 y 1457, ocupó una posición preeminente en el Consejo Real y en otros organismos centrales del gobierno de la Corona en Nápoles. ${ }^{191}$ Allí consiguió beneficios inmensos otorgados por el Magnánimo, ${ }^{192}$ que hizo extensivos a sus posesiones valencianas, ${ }^{193}$ aprovechando su elevada posición para obtener de la Cancillería regia cartas de recomendación destinadas a los oficiales reales del reino de Valencia para que trataran sus negocios «com si foren nostres» [del rey]. Entre otras gracias, en 1439 Alfonso V suspendió todos los pleitos civiles y criminales contra Corella mientras durara su permanencia en la corte napolitana. ${ }^{194}$ En 1442, Joan Roís de Corella salía elegido como diputado primero por el brazo militar. ${ }^{195}$ La privilegiada posición de Corella le sirvió para obtener en 1448 una nueva carta real que le eximía de la jurisdicción de Luis Cornelll, gobernador de Orihuela, a él mismo, a su hijo Joan Roís de Corella, a sus servidores, a sus vasallos y al condado de Cocentaina. Todos los procesos civiles y criminales en los que se vieran involucrados eran avocados por el monarca, quien delegaba su conocimiento en el lugarteniente de gobernador de Orihuela. ${ }^{196}$

191 RYDER, A., El Reino cit., pp. 82-84.

192 El 29 de abril de 1441, el rey le concede una casa en Capua, confiscada a un rebelde (ACA, RC, reg. 2.905, ff. 104v-105v). El 2 de junio de 1442, Alfonso V concede a Corella y a sus sucesores el uso de las insignias reales junto con las propias, más 3.000 ducados sobre las gabelas napolitanas (ibídem, reg. 2.902, ff. 32v-34). El 10 de agosto de 1442, le concede una provisión anual de 500 onzas (ibídem, reg. 2.902, ff. 60v-61v). El 3 de diciembre de 1443, le otorga 3.000 ducados (ibídem, reg. 2.903, ff. 34r-36v). El 1 de abril de 1445 resuelve a su favor un pleito contra Bernat Joan de Cabrera, conde de Módica, quien le debía pagar 6.500 ducados (ibídem, reg. 2.911, ff. 34r-36r). El 27 de agosto de 1448 el rey le exime de una prenda de 1.000 ducados (ibídem, reg. 2.913, ff. 44v-45r).

193 Como la concesión de la acequia de Antella en 1444 (ARV, Real, reg. 257, ff. 45r-46r).

194 ARV, Gobernación, reg. 2.804, m. 4, f. 7r.; ibídem, Mà de lletres reials, ff. 34r-35r. Durante las Cortes de 1443-46, el brazo real pidió que se revocaran todas las provisiones reales que suspedían las ejecuciones de censales en contra de Corella y sus lugares de Elda y Asp (ARV, Real, reg. 500, ff. 18v-19r.)

195 ARV, Generalidad, lib. 705.

196 ARV, Real, reg. 257, f. 140r-v. Corella ya había intentado disfrutar de estas exenciones en 1428, año en el que consiguió una provisión real en este sentido a raíz de sus enfrentamientos con Maça, pero las protestas de los representantes de Orihuela obligaron al rey a anularla (ARV, Real, reg. 40, ff. 43r-44r). 
El orgulloso Maça tropezó siempre con la misma piedra: el favor del rey. Con los Maça, el soberano limitó sus gracias, que fueron pocas. ${ }^{197} \mathrm{La}$ rivalidad entre ambos caballeros influyó en una nueva destitución de Pero Maça a fines de $1447 .{ }^{198}$ Sin embargo, dada la correlación de fuerzas locales y el arraigo de esta familia en su área de influencia, el cargo de gobernador de Orihuela, tras un período de interinidad, pasó a ser desempeñado por Luis Cornell. Por aquellos años, Cornell, cuyo señorío de Alberic estaba enclavado en la gobernación regida por Corella, se enfrentaba al Consejo Real y al gobernador a causa de sus disputas con los Próxita, haciendo gala de la energía propia de la familia. ${ }^{199}$

Los Maça recibieron un rudo golpe en el corazón de su dominio cuando la baronía de Cocentaina - que desde 1437 hasta 1446 había estado en poder de Joan de Próxita, con el cual también pleiteaban - fue vendida a Eximèn Pérez de Corella, quien además este mismo año fue distinguido nada menos que con el título de conde. Por ese motivo, hacia 1449 la enemistad entre las dos familias estaba más viva que nunca, como vimos al principio de este trabajo. Muerto Pero Maça de Liçana en 1448 y con Eximèn Pérez de Corella en Nápoles, la protagonizaban ahora sus hijos, Luis Cornell y Joan Roís de Corella, ${ }^{200}$ que se habían perpetuado en los cargos de los padres. El 16 de diciembre de 1445, Alfonso V había nombrado en expectativa a Luis Cornell como gobernador vitalicio de Orihuela, a la muerte de su padre, para

197 En 1445, Alfonso V confirmó a Pero Maça de Liçana (a) Luis Cornell el ejercicio de la jurisdicción civil y criminal que ya ejercía, sin títulos válidos, sobre Alberic, La Foia, Benifaraig y Rafalet (ARV, Real, reg. 495, ff. 107v-110r), lo que provocó la protesta del brazo real durante las Cortes de 1443-46, por estar situado Alberic en los términos generales de la villa de Alzira, a la cual correspondía la jurisdicción criminal (ARV, Real, reg. 500, f. 36r).

198 ARV, Real, reg. 69, f. 117v.

199 LÓPEZ RODRÍGUEZ, C., «Guerras» cit., pp. 643 y ss. Zurita (XV, 55, p. 410) se refiere a esta contienda y a la disensión que produjo en el reino.

200 Y acaso a estas rencillas se debiera el hecho de que en 1447 algunas personas sembraran discordias entre Joan Roís de Corella y su mujer, Caterina de Villena, hasta el punto de iniciarse un proceso de divorcio (ARV, Real, reg. 69, f. 86r-v). El rey no tardó en intervenir en esta cuestión, mediante escritos al lugarteniente del gobernador, para que se respetara la potestad de Joan Roís de Corella en ordenar su casa a su voluntad (ARV, Gobernación, reg. 2.807, m. 3, f. 25r). Todavía en 1453 había tan gran disensión entre Luis Cornell y el conde de Concentaina que el reino estaba en gran turbación y el rey de Navarra los mandó venir a su corte (ZURITA, XVI, 25, p. 105). La irrupción de Corella en Cocentaina provocó graves conflictos con otros vecinos, como los que se entablaron con la ciudad de Barcelona, en tanto que titular del señorío de Elx i Crevillent, a partir de 1450, por el aprovechamiento de las aguas del Vinalopó (GARRIDO I VALLS, J.-D., «El difícil veïnatge» cit.) 
lo cual valoró los servicios que le había prestado en Italia, ${ }^{201}$ a donde, como sabemos, había zarpado en 1444. Poco después, el 24 de octubre de 1446, se designó a Joan Roís de Corella como gobernador vitalicio de Valencia a la muerte o renuncia de su padre, ${ }^{202}$ nombramiento confirmado el 10 de agosto de 1448 cuando la renuncia de su progenitor al cargo se hizo efectiva. ${ }^{203} \mathrm{El}$ 10 de abril de 1450, el puesto revertió transitoriamente al padre, porque Joan Roís de Corella se trasladó a Nápoles en servicio del rey. ${ }^{204}$ Éste fue otra vez nombrado gobernador el 19 de octubre de 1457, pero ya como nuevo conde de Cocentaina tras la muerte de Eximèn Pérez de Corella, ocurrida dos días antes. ${ }^{205}$ No duró mucho, porque fue destituido en 1458 y sustituido por Pedro de Urrea. ${ }^{206}$ Pero de nuevo fue nombrado gobernador del reino a la muerte de Urrea en 1469. ${ }^{207}$ Tampoco Luis Cornell ejerció su cargo sin alteraciones. En junio de 1449, el nuevo lugarteniente general del rey, Joan Copons, nombrado unos meses antes, le suspendió en su oficio, instigado por Joan Roís de Corella, que pretendía entrar en Orihuela, aunque esta destitución no parece haberse ejecutado. ${ }^{208}$ No sería el último sobresalto. El 25 de noviembre de 1455, fue repuesto como gobernador de Orihuela tras haber sido sustituido por Jaume Rocamora, en fecha que ignoramos. ${ }^{209}$ No obstante estos contratiempos, Luis Cornell se mantuvo en el cargo hasta su muerte en $1463 .{ }^{210}$

\section{EL TRIUNFO DE CORELLA}

Los bandos entre ambas familias continuaban todavía en 1473, con las habituales consecuencias catastróficas para la paz del reino, incluidos los desafíos particulares entre los caballeros. ${ }^{211}$ Sin embargo, desaparecidos los dos principales protagonistas, carecían ya del contenido político que habían ido

\footnotetext{
201 ARV, Real, reg. 419, f. 21v.

202 ARV, Real, reg. 419, ff. 46v-47v.

203 ARV, Real, reg. 419, ff. 68v-69v.

204 ARV, Real, reg. 419, ff. 113r-115r.

205 ARV, Real, reg. 420, ff. 54r-55v, 1457, nov. 1. El juramento del cargo de gobernador del reino de Valencia prestado por Joan Roís de Corella el 1 de noviembre de 1457 en ACA, RC, Cartas Reales Diplomáticas, Papeles varios de Alfonso el Magnánimo, cajas 19-20, núm. 120.

206 MATEU IBARS, J., Los virreyes cit., p. 92.

207 ARV, Real, reg. 421, f. 92r.

208 BARRIO BARRIO, J. A., y CABEZUELO PLIEGO, J. V., «La defensa de los privilegios locales y la resistencia a la centralización política en la Gobernación de Orihuela», Anales de la Universidad de Alicante. Historia medieval, 13 (2003), pp. 29-30. ARV, Real, reg. 420, ff. 18v-19r.

210 BARRIO BARRIO, J. A., y CABEZUELO PLIEGO, J. V., «La defensa de los privilegios» cit., p. 19.

211 ZURITA, XVIII, 61, p. 739.
} 
adquiriendo a mediados de siglo y volvían a tomar el carácter de enfrentamiento meramente particular entre nobles con el que se habían iniciado en la década de 1420. En efecto, los conflictos entre Corella y Maça habían tenido en sus comienzos un componente personal, que radicaba en sus diferentes orígenes sociales y en la competencia territorial por el dominio de un área de influencia. Pero acabaron, además, por adquirir un matiz político. Aunque Corella y Maça militaron en una misma «opinión» en las Cortes de 1417 y en las de 1437, mantuvieron, además de sus grandes disputas personales, una fuerte oposición determinada por su reacción ante los cambios que se introducían en la Corona y por su comprensión del funcionamiento de las instituciones. Esta disensión tardó en cuajar cerca de veinte años, trascendiendo la oposición puramente personal, y desapareció con ellos, lo que es indicativo también del escaso nivel de cultura política de los protagonistas, que solo se define en la medida en que protagonizaban la vida de las instituciones de la Corona y del reino.

Sus comportamientos dispares sintetizan dos actitudes también divergentes de la nobleza ante los cambios políticos que se estaban produciendo durante la primera mitad del siglo XV. Por un lado quienes, como Corella, optaron por la colaboración con la Corona para la reforma y transformación de los aparatos administrativos y militares, se implicaron profundamente en la vida política interior e internacional de la Monarquía, y estuvieron en contacto con las corrientes más innovadoras de Europa, por lo que vieron su posición muy reforzada y recompensados sus servicios. Por otro lado, se alzaban las viejas familias de la nobleza feudal y rural, con concepciones políticas muy arcaicas, pero poseedoras de un poder inmenso y con un dominio social y político bien asentado tras generaciones de hegemonía, y sin las cuales la monarquía no podía gobernar sus reinos, pese a que se mostraran reacias a las novedades institucionales y a una política exterior que no entendían y de la cual no sabían sacar partido. Esta postura le costó a Maça su promoción hacia el estado que quizá le hubiera correspondido en el conjunto de la nobleza si hubiera colaborado con su rey más allá de sus limitados servicios militares durante la guerra de Castilla, en la que tenía grandes intereses personales porque afectaba directamente a sus señoríos. A los Maça, este error estratégico les costó el título nobiliario y su postergación de la alta nobleza que estaba constituyéndose durante el siglo XV. En 1488, según una derrama repartida entre el brazo militar, tanto Pero Maça de Liçana como el conde de Cocentaina estaban entre los doce mayores contribuyentes de la nobleza valenciana. Pero los Maça de Liçana seguían sin título nobiliario, que habían conseguido otras familias con no menos poder y prestigio que el suyo unas 
décadas antes y que por entonces eran los condes de Albaida, Aranda, Aversa, Cardona, Cocentaina, Oliva; el duque de Gandia; el marqués de Elche; el duque de Segorbe, los vizcondes de Xelva y de Gagliano, el marqués de Dénia, y la marquesa de Montcada. Los Maça de Liçana no dejaron de ser una gran familia pero, en el cambiante contexto social del siglo XV, no consiguieron mantener la posición de liderazgo que, según pensaban, les correspondía. En 1454, Bernat Joan, señor de Tous, caballero de la nobleza media agraviado por los ataques de Luis Cornell a sus vasallos, afirmaba «que no és don Luis tan gran senyor que no li puxa hom axí bé marcar sos vassalls dins ço del seu com ell ha fet fer als de ací». ${ }^{212}$

El enfrentamiento entre Pero Maça de Liçana y Eximèn Pérez de Corella responde, pues, a dos pautas de comportamiento muy características de la nobleza del siglo XV en los estadios inmediatamente anteriores a la consolidación de una monarquía absoluta. En su bello libro sobre Pero Maça, Martí de Riquer retrató su vida aventurera y caballeresca. En este trabajo hemos visto la otra cara del personaje: celoso de sus privilegios de clase, conservador frente a las innovaciones introducidas por la Corona, corto de miras en sus planteamientos estratégicos. Hemos seguido su comportamiento en un mundo política y socialmente cambiante, cuyo funcionamiento -educado como estaba en las cortes de Juan I y Martín el Humano, y en el recuerdo de las gestas de sus antecesores y de las hazañas de su abuelo y padre, muertos al servicio de los monarcas de la Casa de Barcelona- no comprendía del todo ni al cual se adaptó, como tampoco simpatizó con la nueva dinastía, a la que dio muy pronto la espalda para conformarse con su poder local. El cambio de época lo entendió mejor un individuo más joven, procedente de un grado inferior de la nobleza, como fue Corella, cuyos antepasados unionistas habían experimentado en carne propia lo que significaba perder el favor del rey. Sirviendo a los Trastamaras, se encumbró sobre los Maça. Al comparar la trayectoria de uno y otro, estamos tentados de pensar que Pero Maça de Liçana pudo sentirse injustamente postergado por su soberano, a cuyos antecesores habían servido sus antepasados con la vida y a quien él mismo había apoyado en su juventud con bravura. Por eso, acaso se identificara con su contemporáneo Ausiàs March, también un duro señor feudal que se adaptó mal a los nuevos tiempos y que vio cómo prosperaban individuos a su parecer sin méritos suficientes, lo que le hizo escribir estos versos, por otro lado tan actuales:

212 ARV, Gobernación, reg. 4.556, f. 6v. Ya en 1444, Cornell y Joan habían pleiteado por los pastos de sus vasallos (ARV, Gobernación, reg. 2.271, m. 2, f. 16r). 
Vidas enfrentadas: Pere Maça de Liçana y Eximèn Pérez de Corella. Enemistad personal,...
«O gent del món!
Obriu los hulls per veure
com no és ver
lo que veritat sembla,
e que honors,
la glòria o ffama,
per les virtuts
per null temps s'atengeren». ${ }^{213}$

$\overline{213}$ Poesies, ed. a cura de Pere Bohigas, Barcelona, 1955, vol. IV, núm. CIV, p. 111. 